\title{
Size-resolved morphological properties of the high Arctic summer aerosol during ASCOS-2008
}

\author{
Evelyne Hamacher-Barth ${ }^{1}$, Caroline Leck ${ }^{1}$, and Kjell Jansson ${ }^{2}$ \\ ${ }^{1}$ Department of Meteorology, Stockholm University, 10691 Stockholm, Sweden \\ ${ }^{2}$ Department of Materials and Environmental Chemistry, Stockholm University, 10691 Stockholm, Sweden \\ Correspondence to: Evelyne Hamacher-Barth (evelyne@ misu.su.se)
}

Received: 27 November 2015 - Published in Atmos. Chem. Phys. Discuss.: 19 January 2016

Revised: 4 May 2016 - Accepted: 6 May 2016 - Published: 31 May 2016

\begin{abstract}
The representation of aerosol properties and processes in climate models is fraught with large uncertainties. Especially at high northern latitudes a strong underprediction of aerosol concentrations and nucleation events is observed and can only be constrained by in situ observations based on the analysis of individual aerosol particles. To further reduce the uncertainties surrounding aerosol properties and their potential role as cloud condensation nuclei this study provides observational data resolved over size on morphological and chemical properties of aerosol particles collected in the summer high Arctic, north of $80^{\circ} \mathrm{N}$.

Aerosol particles were imaged with scanning and transmission electron microscopy and further evaluated with digital image analysis. In total, 3909 aerosol particles were imaged and categorized according to morphological similarities into three gross morphological groups: single particles, gel particles, and halo particles. Single particles were observed between 15 and $800 \mathrm{~nm}$ in diameter and represent the dominating type of particles ( $82 \%)$. The majority of particles appeared to be marine gels with a broad Aitken mode peaking at $70 \mathrm{~nm}$ and accompanied by a minor fraction of ammonium (bi)sulfate with a maximum at $170 \mathrm{~nm}$ in number concentration. Gel particles (11\% of all particles) were observed between 45 and $800 \mathrm{~nm}$ with a maximum at $154 \mathrm{~nm}$ in diameter. Imaging with transmission electron microscopy allowed further morphological discrimination of gel particles in "aggregate" particles, "aggregate with film" particles, and "mucus-like" particles.

Halo particles were observed above $75 \mathrm{~nm}$ and appeared to be ammonium (bi)sulfate ( $59 \%$ of halo particles), gel matter $(19 \%)$, or decomposed gel matter $(22 \%)$, which were inter-
\end{abstract}

nally mixed with sulfuric acid, methane sulfonic acid, or ammonium (bi)sulfate with a maximum at $161 \mathrm{~nm}$ in diameter.

Elemental dispersive X-ray spectroscopy analysis of individual particles revealed a prevalence of the monovalent ions $\mathrm{Na}^{+} / \mathrm{K}^{+}$for single particles and aggregate particles and of the divalent ions $\mathrm{Ca}^{2+} / \mathrm{Mg}^{2+}$ for aggregate with film particles and mucus-like particles. According to these results and other model studies, we propose a relationship between the availability of $\mathrm{Na}^{+} / \mathrm{K}^{+}$and $\mathrm{Ca}^{2+} / \mathrm{Mg}^{2+}$ and the length of the biopolymer molecules participating in the formation of the three-dimensional gel networks.

\section{Introduction}

Aerosol particles have major impacts on the climate of our planet. They alter the planetary albedo both directly by absorbing and scattering sunlight and indirectly by modifying the reflectivity, lifetime, and extent of clouds (Twomey, 1977; Albrecht, 1989; Solomon et al., 2007). Despite the known importance of the effects of aerosol particles on clouds, they still give rise to large uncertainties in climate models (Schimel et al., 1996; Penner et al., 2001; Forster et al., 2007). Detailed model analyses have contributed to an enhanced understanding of the parametric uncertainties in global aerosol models and point towards significant uncertainties arising from an incomplete representation of aerosol processes and emissions in the models (e.g. Lee et al., 2013; Carslaw et al., 2013; Mann et al., 2014). Especially for high northern latitudes, a strong underprediction of aerosol particle concentrations and nucleation events in summer compared to measurements is recognized (Mann et al., 2014). 
This can lead to an insufficient representation of cloud condensation nuclei $(\mathrm{CCN})$, which can activate and form cloud droplets, in models. Moreover, the microphysical properties of the cloud droplets are strongly related to the size, chemical composition, morphology, and state of mixture of the activated CCN. Size-resolved data based on the analysis of individual particles are therefore indispensable for an appropriate parameterization of aerosol particles within aerosol models.

The sources of aerosol particles in the Arctic are subjected to large regional and seasonal differences. In late winter/spring, a pronounced anthropogenic influence on the Arctic is observed, a phenomenon known as Arctic haze (Shaw, 1995). During that time the Arctic air mass expands southwards towards Eurasia and North America and anthropogenic emissions are transported into the Arctic where they remain for prolonged times (Shaw, 1995; Douglas and Sturm, 2004). The aerosol during periods of Arctic haze is characterized by relatively high concentrations of aged aerosol predominantly in the accumulation mode (Shaw, 1984; Heintzenberg and Leck, 1994; Ström et al., 2003; Engvall et al., 2008; Korhonen et al., 2008). The air masses arriving in summer, however, originate from sectors over the oceans with limited man-made activities and the transport into the Arctic is slower compared to winter conditions (Stohl, 2006). The summer conditions are thus much more pristine and the aerosol shifts from a dominance of the accumulation mode to the Aitken mode (Heintzenberg et al., 2006, 2015; Engvall et al., 2008).

Over the high Arctic pack ice north of $80^{\circ}$, number concentrations of $\mathrm{CCN}$ show a large temporal variability, ranging over 2 to 3 orders of magnitude but usually below $100 \mathrm{~cm}^{-3}$ and occasionally less than $1 \mathrm{~cm}^{-3}$ (Lannefors et al., 1983; Bigg et al., 1996; Bigg and Leck, 2001a; Mauritsen et al., 2011; Leck and Svensson, 2015). These relatively low $\mathrm{CCN}$ concentrations have a significant impact on the formation of low-level (stratiform) clouds prevalent in the high Arctic summer. Mauritsen et al. (2011) identified a regime with very low $\mathrm{CCN}$ concentrations $\left(<10 \mathrm{~cm}^{-3}\right)$ where cloud formation is limited mainly by the availability of CCN. Such low CCN concentrations occur as a result of weak local aerosol sources and effective wet deposition (Nilsson and Leck, 2002; Held et al., 2011a, b; Heintzenberg et al., 2006; Leck and Svensson, 2015) at the marginal ice zone and over the pack ice.

The physical and chemical properties which determine the ability of the summer high Arctic aerosol particles to act as $\mathrm{CCN}$ are still not very well understood. Attempts to theoretically predict concentrations of $\mathrm{CCN}$ in closure studies resulted in over- and underpredictions of the observed CCN concentrations (Zhou et al., 2001; Bigg and Leck, 2001a; Lohman and Leck, 2005; Martin et al., 2011; Leck and Svensson, 2015). The most recent closure study by Leck and Svensson (2015) simulated the cloud nucleation process by assuming Köhler theory together with a Lagrangian adiabatic air parcel model that solves the kinetic formulation for con- densation of water on size-resolved aerosol particles. The authors suggested a larger fraction of the internally/externally mixed water-insoluble particles in the smaller aerosol size ranges as well as kinetically restricted growth of the activated particles. The non-water soluble particle fraction was suggested to physically and chemically behave as polymer gels ${ }^{1}$ with a dichotomous behaviour (low hygroscopic growth factor but a high CCN activation efficiency) in cloud droplet activation as a result of the interaction of the hydrophilic and hydrophobic entities on the structures of the high Arctic polymer gels (Orellana et al., 2011). On average $32 \%$ of the Arctic surface ocean DOM assembled as microgels (Orellana et al., 2011), a significantly higher percentage than reported for other ocean regions (10\%; Chin et al., 1998; Verdugo et al., 2004). All together these findings strongly supported the previously unverified hypothesis of a link between cloud formation and polymer gels in the surface microlayer $(<1000 \mu \mathrm{m}$ thick at the air-sea interface $)$ of the high Arctic open leads (Bigg et al., 2004; Leck and Bigg, 1999, 2005b, 2010; Leck et al., 2002; Bigg and Leck, 2008).

The transport of marine gels into the atmosphere is thought to happen via the burst of air bubbles at the air-sea interface. Air bubbles rising within the water column scavenge surfaceactive organic matter, especially from the surface microlayer to their outer walls (Wotton and Preston, 2005). Bursting of the bubbles at the water surface produces small jet and film drops containing organic surface-active compounds, debris of phytoplankton, bacteria, viruses, and sea salt (Blanchard and Woodcock, 1957; Blanchard, 1971; Blanchard and Syzdek, 1988; Gershey, 1983; O’Dowd et al., 1999) that are transported further up into the atmosphere through turbulent mixing processes. However, studies of individual particles by Bigg and Leck (2001b, 2008), Leck et al. (2002), and Leck and Bigg $(2005 a, b)$ over the perennial ice have failed to find evidence of sea salt particles of less than $200 \mathrm{~nm}$ in diameter. In the Arctic breaking waves as a source of bubbles are rare due to low wind speeds and short fetches between the ice floes (Tjernström et al., 2012). Even in the absence of winddriven breaking waves a recent study has now confirmed both the presence and temporal variability of a population of bubbles within the open leads (Norris et al., 2011). The considered mechanisms for bubble formation and mixing were induced by changes in gas saturation. Other possible bubble formation mechanisms are respiration from algae and phytoplankton (Medwin, 1970; Johnson and Wangersky, 1987) and the release of trapped air from melting ice (Wettlaufer, 1998).

\footnotetext{
${ }^{1}$ Phytoplankton and bacteria in surface seawater produce varying amounts of mucus- or gel-like matter comprised of biopolymers like proteins, polysaccharides, or lipids that form three-dimensional networks inter-bridged with divalent ions, preferably $\mathrm{Ca}^{2+}$ and $\mathrm{Mg}^{2+}$. Embedded in the polymer network is a high content of water $(99 \%)$ that prevents the network from collapsing (Chin et al., 1998). This type of supramolecular organization is referred to as marine gels (Verdugo, 2012 gives a review).
} 
Due to the remoteness and the harsh conditions in the high Arctic, the number of aerosol studies from this region is limited with data available only from four expeditions onboard the Swedish icebreaker Oden during the summers of 1991, 1996, 2001, and 2008 (Leck et al., 1996, 2001, 2004; Tjernström et al., 2014). These expeditions took advantage of the pristine conditions during the Arctic summer when the Arctic is greatly separated from polluted mid-latitudinal sources, which provided a unique opportunity to study aerosol particles from predominantly natural sources. All other Arctic studies on aerosol chemical composition, morphology, and state of mixture were either performed during winter/spring when the transport of polluted aerosol from lower latitudes into the high Arctic was strong (e.g. Hara et al., 2003; Xie et al., 2007; Winiger et al., 2015) and/or they were located further south and outside of the pack-ice area. The latter event would allow missing potential aerosol sources from the packice area and at the same time include anthropogenic pollution (e.g. Geng et al., 2010; Chi et al., 2015).

An investigation of size, chemical composition, morphology, and state of mixture on the level of individual aerosol particles is required to further reduce the uncertainties surrounding the $\mathrm{CCN}$ properties that promote or suppress cloud droplet formation over the pack-ice area. The present study will make use of aerosol particles collected during the most recent icebreaker expedition under the name ASCOS (Arctic Summer Cloud and Ocean Study) 2008. The Swedish icebreaker Oden departed from Longyearbyen on Svalbard on 2 August and returned on 9 September 2008 (Fig. 1). After traversing the pack ice northward, the icebreaker was moored to an ice floe and drifted passively with it around $87^{\circ} \mathrm{N}$ between 12 August and 1 September (Tjernström et al., 2014). We used electron microscopy (scanning electron microscopy (SEM) and transmission electron microscopy (TEM)) to image aerosol particles at high resolution and subsequent digital image analysis to objectively assess size and morphology of the particles on an individual basis. Earlier studies north of $80^{\circ}$ focused on a qualitative description of the aerosol in the high Arctic (Leck and Bigg, 2005b, 2008, 2010; Bigg and Leck, 2001b, 2008) complemented with bulk chemical analyses (Leck et al., 2002, 2013; Leck and Svensson, 2015; Lohman and Leck, 2005).

Firstly, by individually screening close to 4000 aerosol particles collected during the ice drift with SEM and subsequent digital mapping, we gained size-resolved information on the aerosol population as a whole. The obtained number size distribution was compared with measurements from an independent method (Tandem Differential Mobility Particle Sizer, TDMPS) to verify that a representative fraction of the aerosol population was captured with SEM. Secondly, we sorted all mapped particles according to morphological differences and a separate number size distribution for each of the morphological types was obtained. Thirdly, to obtain deeper insights into the morphological features of the collected particles and to simultaneously assess their elemental

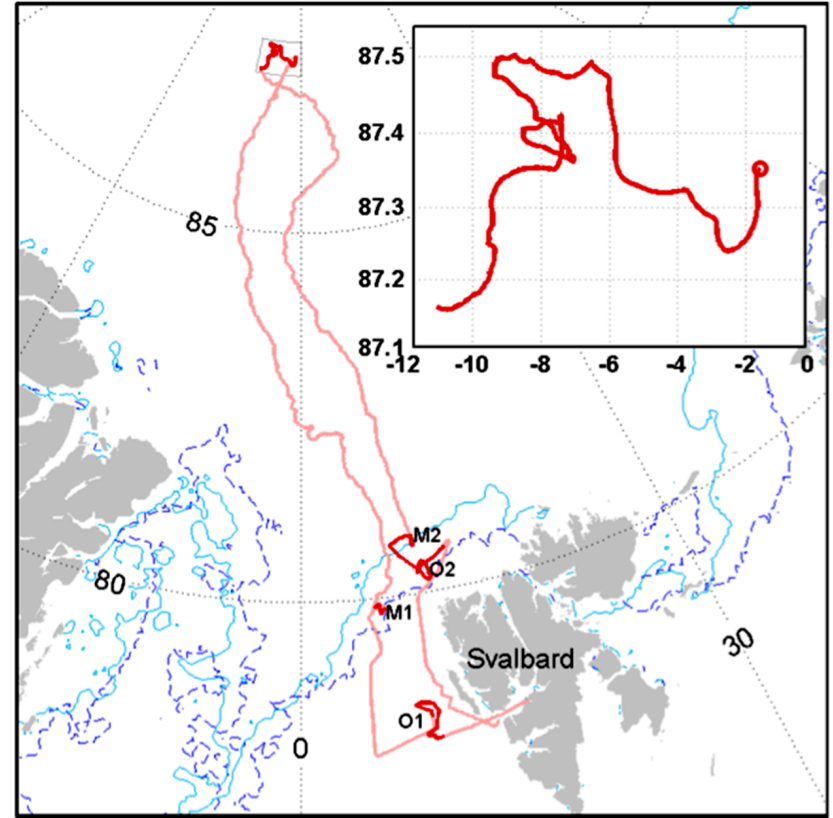

Figure 1. Track of the icebreaker Oden in the Arctic (pink). The path during the ice drift is shown in the insert (red line). The circle indicates the start of the ice drift; the ice edge (thin blue line) was passed on 12 August 2008.

composition with EDX spectroscopy, we investigated a subpopulation of aerosol particles in TEM at very high resolution.

\section{Methods for sampling of airborne aerosol particles during ASCOS}

\subsection{Collection of airborne particles}

\subsubsection{The sampling inlet}

A PM 10 -inlet ( $9 \mathrm{~cm}$ inner diameter) was deployed at ambient conditions $(85-100 \%$ relative humidity $(\mathrm{RH})$ and temperatures around $0^{\circ} \mathrm{C}$ ) to eliminate particles $>10 \mu \mathrm{m}$ in equivalent aerosol dynamic diameter from the sampled air. To optimize the distance from the sea surface and the ship's superstructure, the inlet was located forward $25 \mathrm{~m}$ above the sea surface and $3 \mathrm{~m}$ above the roof of the laboratory container on the fourth deck of the icebreaker. Direct contamination from the ship was excluded by using a pollution controller, located directly after the inlet pipe that passed through the roof of the container. Provided that the wind was within $\pm 70^{\circ}$ of the direction of the bow and stronger than $2 \mathrm{~m} \mathrm{~s}^{-1}$, no pollution reached the sample inlets (Leck et al., 1996). Directly downstream from the pollution sensor the electrostatic precipitator and the TDMPS were connected to the inlet with short stainless steel tubes (length ca. $1 \mathrm{~m}$ ). To ensure that the sampling conditions and losses were the same for both instruments, the 
inlet take-offs for the two instruments were placed closely together. The temperature in the container was kept at $20^{\circ} \mathrm{C}$ which resulted in an RH of $20 \%$ in the secondary lines during sampling. See Leck et al. (2001) for more details of the set-up for the sampling of aerosol particles.

Volatile compounds on particle surfaces and weakly bound water molecules were probably lost during the sampling procedure. In the Arctic, the concentration of volatile compounds is generally lower than at lower latitudes (Bates et al., 1987), and losses due to evaporation can be considered very small.

\subsubsection{The electrostatic precipitator}

Using the electrostatic precipitator the aerosol particles were collected directly onto $3 \mathrm{~mm}$ copper 300 mesh Formvarcoated TEM grids (TED PELLA Inc.; Dixkens and Fissan, 1999; Leck and Bigg, 2008). Formvar-coated grids were chosen because of the hydrophilic and thus polar nature of the Formvar film (Rocha et al., 2005). The aerosol particles were charged at the inlet of the precipitator by a ${ }^{63} \mathrm{Ni}$ beta-emitting radioactive source and precipitated by a $12 \mathrm{kV} \mathrm{cm}^{-1}$ electric field between the inlet and the collecting grid surface. The flow rate was kept very low $\left(0.17 \mathrm{~mL} \mathrm{~s}^{-1}\right)$ in order to collect particles up to $\sim 1 \mu \mathrm{m}$ in diameter. The collection efficiency of the electrostatic precipitator was intercompared with a TSI 1236 Nanometer Aerosol Sampler $\left({ }^{63} \mathrm{Ni}\right.$ betaemitting radioactive source and sample flow of $1 \mathrm{~L} \mathrm{~min}^{-1}$ ) mounted side-by-side with the electrostatic precipitator. Both collected a small but statistically significant number of particles $<25 \mathrm{~nm}$ in diameter. The precipitator took samples for 6 to $12 \mathrm{~h}$. Before and after sampling the grids were placed within a grid holder box in a sealed plastic bag and stored in a desiccator at a constant temperature of $20^{\circ} \mathrm{C}$.

\subsubsection{The TDMPS-sampling system}

The TDMPS-sampling system to measure the number size distributions of dry $(20 \% \mathrm{RH})$ sub-micrometre particles used pairs of differential mobility analysers (DMAs). The TSI 3010 counters in the DMAs were size and concentration calibrated against an electrometer and the TSI 3025 counters for particle sizes below $20 \mathrm{~nm}$ in diameter according to Stolzenburg (1988). This set up yielded a complete number size distribution from 3 to $800 \mathrm{~nm}$ diameter scanned over 45 size channels every 10-20 min. Further details of the TDMPS system can be found in Heintzenberg and Leck (2012). NIST (National Institute of Standards Technology) traceable calibration standards of polystyrene latex spherical particles were used to determine error in determination of the mobility diameter to $\pm 5 \%$ (Wiedensohler et al., 2012).

In order to compare the number size distribution obtained from the precipitator samples (Sect. 2.1.2) with those simultaneously recorded by the TDMPS, we assumed median particle number diameters for each of the 45 TDMPS size chan- nels. The particle diameters were then merged to form a complete set of diameters across the TDMPS measuring interval.

\subsection{Image recording and elemental analysis}

\subsubsection{Imaging with SEM}

The samples were investigated with a high-resolution SEM (JEOL JSM-7401) under high vacuum conditions, at less than $9.63 \times 10^{-5} \mathrm{~Pa}$ (Stevens et al., 2009). A detailed description of the set-up of the scanning electron microscope can be found in Hamacher-Barth et al. (2013). The Gentle Beam mode of the microscope was used to minimalize radiation damage of the aerosol particles, avoid surface charge-up, and demagnify the electron beam diameter (Michael et al., 2010). Correction for stigmatism and focusing of the electron beam was done every time before imaging an aerosol particle. The grey scale (contrast and brightness) was adjusted automatically before recording an image.

The imaging of the aerosol particles aimed to account for an uneven distribution of the particles on the TEM grid and to capture a representative fraction of the aerosol particles. In brief, particles were imaged at a magnification of 40000 on the TEM grid squares along a diagonal from the centre of the grid to the edge on six to eight squares of the TEM grid. Each square was screened systematically to capture a representative fraction of the aerosol population. For a detailed description of the screening procedure see Hamacher-Barth et al. (2013).

\subsubsection{Imaging with TEM}

To image the samples with TEM they have to be coated by a thin metal layer. Evaporation of a thin heavy metal coating at an oblique angle onto the sample increases the mass contrast and accentuates the topography of the aerosol particle by producing a shadow (Williams and Carter, 1996). Furthermore, shading has the advantage that the metal cover protects the aerosol particles against heating by the electron beam during examination, especially at high magnifications. It is also advantageous that in case of any evaporation from the aerosol particle the metal replica of the aerosol particle is still visible.

The aerosol particles were shaded with platinum $(\mathrm{Pt})$ at an angle of $\arctan (0.5)=26^{\circ}$ (Okada, 1983) in a vacuum chamber at $10^{-6}$ mbar. Pt was evaporated from a Pt wire $(\varnothing 0.2 \mathrm{~mm}, 20 \mathrm{~mm}$ length). The Pt wire was drawn around a tungsten $(\mathrm{W})$ wire and evaporated clusters of $\mathrm{Pt}$ atoms when the $\mathrm{W}$ wire was heated up electrically by a $85 \mathrm{~mA}$ current for $30 \mathrm{~s}$. The shading procedure produces a layer of $\mathrm{Pt}$ particles of $1-2 \mathrm{~nm}$ in diameter on the TEM grid.

After shadowing the TEM grids were examined in TEM using a JEOL JEM-2100 high-resolution instrument, equipped with a $\mathrm{LaB}_{6}$ filament and a $\mathrm{Si} / \mathrm{Li}$ detector crystal. The TEM grid containing the aerosol particles was mounted on a sample holder made of beryllium (Be) to avoid 


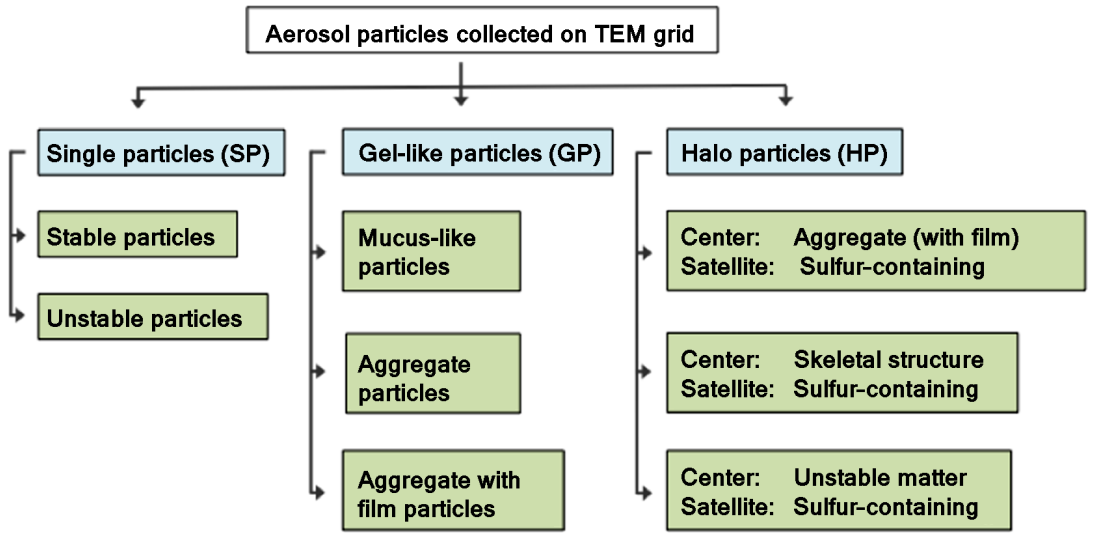

Figure 2. Scheme of the aerosol particle types collected on Formvar grid; the particles observed with SEM are shaded in light blue, and particles observed in TEM are shaded in light green.

background signals from the sample holder material in the EDX measurements (see Sect. 2.2.3). A CCD camera (Gatan SC1000 Orius, 11 Megapixel) in bottom mount position was used to image the aerosol particles. Images were taken at high vacuum, at less than $35 \times 10^{-5} \mathrm{~Pa}$, and at an accelerating voltage of $100 \mathrm{keV}$.

Particles were imaged on TEM grid squares along a diagonal from the centre of the grid to the edge on six to eight squares. To avoid imaging of particles that were damaged by prior imaging with SEM, an area of the grid was chosen which had not been exposed to any electron beam at high magnifications before. Screening each square for individual particles was done at a magnification of 30000 , and images were taken at magnifications between 25000 and 80000 .

\subsubsection{Elemental X-ray spectroscopy}

The elemental analyses were performed using an energy dispersive X-ray detector JED-2300 attached to the JEM-2100 TEM. In order to avoid time-consuming realignment of the electron beam and focusing procedures, the EDX analyses were also performed at an accelerating voltage of $100 \mathrm{kV}$. The energy range measured was $0-20 \mathrm{keV}$, the counting rate was typically 1053 counts s $^{-1}$, the lifetime was $30 \mathrm{~s}$, the real time was $33 \mathrm{~s}$, and the dead time was $10 \%$. Generally EDX spectroscopy allows the detection of elements $\geq \mathrm{Be}$ as their photon energies are above $100 \mathrm{eV}$ and thus lie within the $\mathrm{X}$ ray region of the electromagnetic spectrum (Egerton, 2008). Nevertheless, the detection of light elements like C, N, and O that are typical for organic compounds can be difficult on a Formvar-coated copper grid since the signal intensity can be biased by attenuation of the X-ray signal through absorption by the adjacent copper grid. Therefore these elements were not reliably detectable and are not part of this study.

Blank grids shadowed with platinum were used to identify the background noise and signals from the TEM grid including copper from the grid and the Formvar film and the
Table 1. Numbers and percentage of total for single particles (SP), gel-like particles (GP), and halo particles (HP) imaged with SEM and used for calculating the number size distributions.

\begin{tabular}{lrrrr}
\hline & $15-80 \mathrm{~nm}$ & $80-200 \mathrm{~nm}$ & $>200 \mathrm{~nm}$ & $\begin{array}{r}\text { Sum } \\
(\% \text { of total })\end{array}$ \\
\hline $\begin{array}{l}\text { Single particles } \\
\text { (\% of total SP) }\end{array}$ & 2609 & 573 & 57 & 3239 \\
$(80 \%)$ & $(18 \%)$ & $(2 \%)$ & $(82 \%)$ \\
\hline Gel particles & 97 & 198 & 108 & 403 \\
$(\%$ of total GP) & $(24 \%)$ & $(49 \%)$ & $(27 \%)$ & $(11 \%)$ \\
\hline Halo particles & 9 & 95 & 163 & 267 \\
$(\%$ of total HP) & $(3 \%)$ & $(36 \%)$ & $(61 \%)$ & $(7 \%)$ \\
\hline & & Total number of particles & 3909 \\
& & & $(100 \%)$ \\
\hline
\end{tabular}

Pt shadowing. The EDX spectra of blank grids showed only signals from Pt, the supporting copper TEM grid, and carbon and oxygen signals from the Formvar substrate film.

\subsubsection{Digital image analysis}

Images taken with SEM at a magnification of 40000 were evaluated using an optimized commercial image processing software (Aphelion ${ }^{\mathrm{TM}}$ Dev 4.10). In brief, the maximal intensity of the neighbouring background of each aerosol particle was determined. Using exactly the same image but including the aerosol particle allowed the separation of the particle and measurement of the particle area in pixels (Hamacher-Barth et al., 2013). The particle size was calculated according to Eq. (1)

$D_{\mathrm{pa}}=2 \sqrt{\text { Area } / \pi}$,

with $D_{\mathrm{pa}}$ as the particle equivalent diameter, which is the diameter of a circle that comprises the same area as the aerosol particle projected onto a two-dimensional surface (Allen, 1997; Hinds, 1999). The value for the area is calculated from 


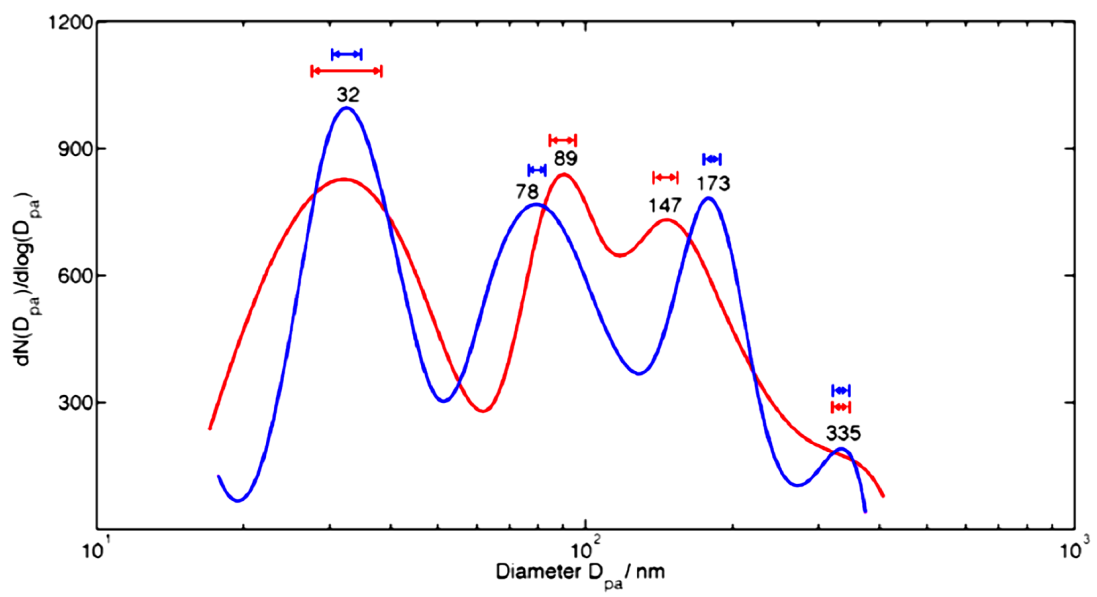

Figure 3. Number size distribution of the total aerosol collected for this study with the red line representing the SEM-derived particle number distribution, and the red error bars representing the error in size determination retrieved from calibration measurements described in Hamacher-Barth et al. (2013). The blue line depicts the number size distribution from simultaneous Tandem Differential Mobility Particle Sizer measurements, and the blue error bars depict a $5 \%$ uncertainty of the data (Wiedensohler et al., 2012).
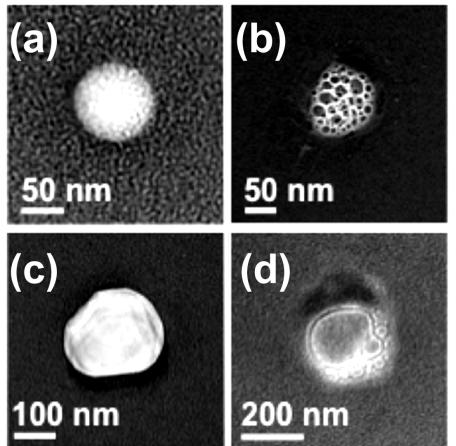

Figure 4. Examples for single particles observed with TEM: (a) a particle stable under the beam of the electron microscope; (b) a particle with a skeletal structure typical for decomposed gel matter; (c) a particle stable under the electron beam; and (d) an example for a particle that is unstable under the electron beam.

the number of pixels counted for each particle. A number size distribution of the aerosol sample was obtained using MATLAB 2011a and the freely available software package EasyFit.

\section{Results and discussion}

Firstly, to verify that a representative fraction of the aerosol population has been captured with SEM, we calculated a number size distribution of all aerosol particles and compare it with measurements from TDMPS. Secondly, we sorted all particles imaged according to morphological similarities into three gross groups: single particles (SP), gel-like particles (GP), and halo particles (HP), shown in Fig. 2. Thirdly, to obtain more subtle insights into the morphological features of the collected aerosol particles and simultaneously assess their elemental composition we investigated a subpopulation of the aerosol particles with TEM and EDX spectroscopy at very high resolution.

\subsection{Total number size distributions}

In order to derive an overall number size distribution we imaged in total 3909 aerosol particles at a magnification of 40000 with SEM. The number size distribution of all imaged aerosol particles exhibited an Aitken mode at $32 \mathrm{~nm}$ in diameter. In the accumulation mode region maxima are observed at 89 and $147 \mathrm{~nm}$ with a shoulder at $335 \mathrm{~nm}$ (see Fig. 3, red line). Hamacher-Barth et al. (2013) used the same image mapping method as in this study and determined the error of sizing for polystyrene latex spheres of several diameter sizes between 20 and $900 \mathrm{~nm}$. The error values are displayed in Fig. 3 as red arrows. For the TDMPS number size distribution we assumed an error of $5 \%$ in determining the mobility diameter across the whole measuring interval (Wiedensohler et al., 2012). The two approaches show an overall good agreement between their number size distributions with a similar modal structure, an Aitken mode below $80 \mathrm{~nm}$, and an accumulation mode at higher diameters. The reduced particle number concentration in the Aitken mode seen by SEM was probably caused by a partly weak contrast of the particles to the Formvar film, which resulted in either an underestimation of the size or the particles remaining undetected. The accumulation mode was separated into a double peak with particle number maxima at 89 and $147 \mathrm{~nm}$ in SEM and 106 and $158 \mathrm{~nm}$ in diameter in TDMPS. The aerosol particles at diameters $>100 \mathrm{~nm}$ often showed a patchy and inhomogeneous appearance, which might have lead to an underestimation of their size and the observed shift to smaller diameters 


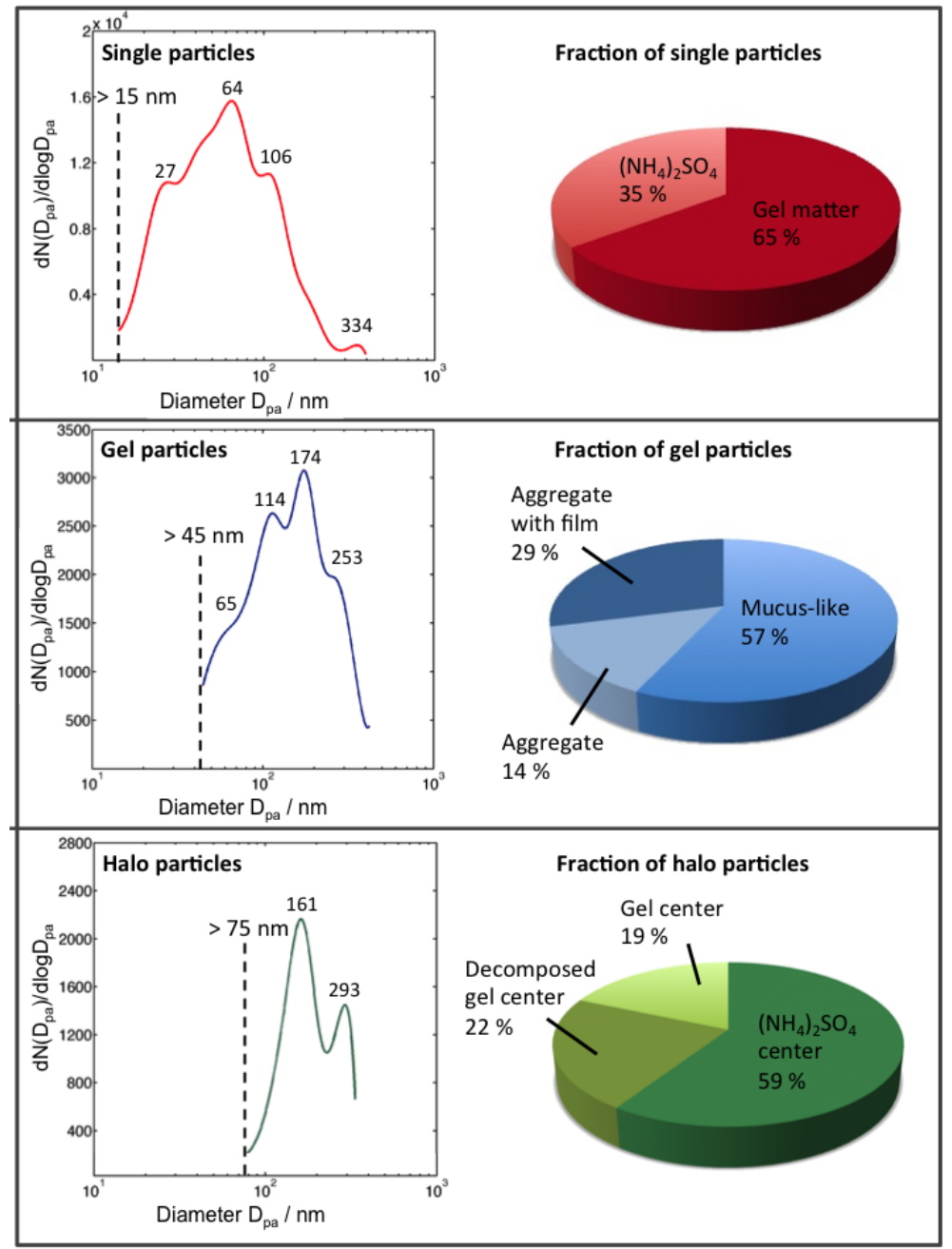

Figure 5. SEM number size distribution of the particle types (single particles, gel-like particles, and halo particles) evaluated for this study (on the left) plus the fraction of the different subgroups of particles derived from TEM (on the right). The dashed line in each figure marks the lowest diameter at which the respective particle type appears.

in SEM with that of $147 \mathrm{~nm}$ compared to $173 \mathrm{~nm}$ in TDMPS and broadening of the maximum at $335 \mathrm{~nm}$.

In general, the number size distributions determined for particles larger than $20 \mathrm{~nm}$ in diameter showed modal features typical for aerosol particles collected in the high Arctic summer boundary layer: an Aitken mode between 26 and $80 \mathrm{~nm}$ and a multimodal accumulation mode between 80 and $1000 \mathrm{~nm}$ (Covert et al., 1996; Heintzenberg et al., 2006; Heintzenberg and Leck, 2012) with the so-called Hoppel minimum around $80 \mathrm{~nm}$ in between (Hoppel, 1986).

\subsection{Single particles}

SP seen by SEM appeared as single entities that mostly contrasted sharply and thus could be easily separated from their Formvar background for diameters $>40 \mathrm{~nm}$. At smaller diameters, however, the contrast to the background was often weak and probably resulted in an underestimation of particle size or non-detection of particles. Imaged examples of SP are shown in Fig. 4. Of the 3909 particles that were mapped, SP were the overall dominating type of particles with $82 \%$ of the total aerosol particles attributed to this group (Table 1). They were observed over the whole size range between 15 and $800 \mathrm{~nm}$ in diameter with a broad Aitken mode peaking at $64 \mathrm{~nm}$ accompanied by a less pronounced peak at $27 \mathrm{~nm}$. The majority of SP (80\%) appeared in the Aitken mode size region and below $80 \mathrm{~nm}$ in diameter (Table 1). In the accumulation mode size range, $18 \%$ of SP appeared between 80 and $200 \mathrm{~nm}$ with a maximum at $106 \mathrm{~nm}$ in diameter and the remaining $2 \%$ of the SP were detected in diameter sizes $>200 \mathrm{~nm}$ (Table 1). We observed that $35 \%$ of the SP partly evaporated under the SEM electron beam but retained their outer shape on the timescale of minutes (Fig. 5, upper panel). Also, at a higher magnification using TEM, the same behaviour was seen for $30 \%$ of the particles. We ten- 
tatively assigned these particles to be ammonium (bi)sulfate particles. We were guided by the results published by Heard and Wiffen (1969) and Bigg and Leck (2001b) where particles with the same morphological features and instability under the electron microscope were made up by ammonium sulfate, bisulfate, or methane sulfonate mixtures. The presence of ammonium sulfate or bisulfate particles would be supported by the fact that ammonia has been reported to be the predominant base in the remote marine troposphere (Söderlund, 1982) that undergoes primarily acid-base reactions with non-sea salt $\mathrm{H}_{2} \mathrm{SO}_{4}$, an oxidation product of biogenic dimethyl sulfide (DMS; Quinn et al., 1987). Leck and Persson confirmed the presence of ammonia bisulfate particles both along the marginal ice edge and over the inner parts of the pack ice. Over remote marine locations at lower latitudes, Mészáros and Vissy (1974) observed ammonium bisulfate concentrations up to $38 \%$ and on average $24 \%$ contained the highest particle concentrations between $100 \mathrm{~nm}$ and $1 \mu \mathrm{m}$ in diameter. In the literature, chemical tests have been used to identify ammonium and sulfate in samples investigated by TEM (Bigg and Leck, 2001b). Such tests were not implemented during this study since the use of chemicals would have added additional mass onto the particles. This would have altered the size and the morphology of the particles and hampered the investigation of the aerosol particles with TEM and EDX spectroscopy.

The presence of biogenic nitrate as a counter ion to ammonium can be considered rather unlikely since the formation of ammonium nitrate happens only after all sulfate has been neutralized (Kuhn et al., 2010). Nitrate concentrations from impactor measurements during ASCOS show nitrate values that are 1 order of magnitude lower than sulfate concentrations at the same time, usually below $0.1 \mathrm{nmol} \mathrm{m}^{-3}$ (C. Leck, personal communication, 2015). Moreover, ammonium nitrate does not evaporate and is stable under the electron beam (Rao et al., 1989). To minimize biases due to evaporative losses and beam damage the ammonium sulfate particles were imaged as quickly as possible. Figure 6 (upper panel) shows the number size distribution of the ammonium sulfate particles derived from the TEM images with a maximum at $172 \mathrm{~nm}$ in the accumulation mode.

The remaining $65 \%$ of the imaged particles (Fig. 5, upper panel) was stable under the heat of the electron beam and showed no sign of evaporation or changes in morphology. Some of those particles appeared as skeletal structures (Fig. 4b) typical for decomposed gel matter that collapsed and merged to an unstructured flat appearance after exposure times to the electron beam significantly longer than the justified time for imaging of the particles. None of the SP showed an apparently crystalline appearance that could be attributed to sea salt or any other inorganic crystalline matter.
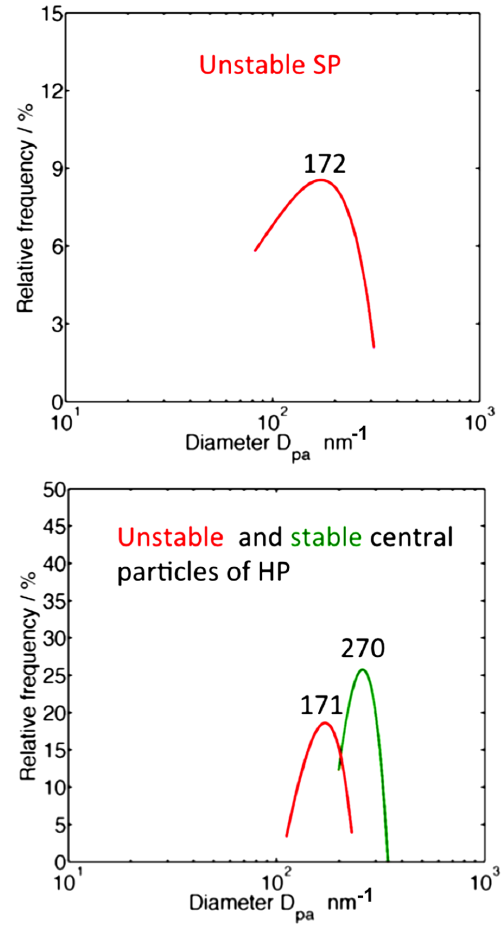

Figure 6. Number size distributions obtained from TEM images. Upper panel shows unstable SP while the lower panel exhibits central particles of HP. The red line represents the unstable central particles, while the green line represents the stable central particles comprising "aggregate", "aggregate with film", and skeletal particles.

\subsection{Gel-like particles}

Aerosol particles classified as GP using SEM showed an amorphous texture with an inhomogeneous distribution of pixel intensity. Their diffuse structure and weak contrast to the Formvar film suggested that these particles predominantly contain light elements like $\mathrm{C}, \mathrm{H}, \mathrm{N}$, and $\mathrm{O}$, which are typical components of organic matter. The contrast between the particles and the Formvar film provides (indirect) information about the elemental composition of the aerosol particle since the number of the detected secondary electrons increases with increasing atomic number of the elements present in the aerosol particle (Zhou et al., 2006), suggesting that the aerosol particles under investigation are built up by matter of biological origin. The potential similarity in chemical composition between the GP and the Formvar film might have lead to an underestimation of the particle size which resulted in the shift of the higher accumulation mode peak at $173 \mathrm{~nm}$ in TDMPS to $147 \mathrm{~nm}$ in the total number size distribution (Fig. 3).

GP appeared in the Aitken mode at diameters above $45 \mathrm{~nm}$ but were most frequently observed in the accumulation mode with a maximum at $174 \mathrm{~nm}$, covering all sizes up to $800 \mathrm{~nm}$ (Fig. 5, middle panel). In total $11 \%$ of the 3909 particles 
Table 2. Fraction of particles containing the ions $\mathrm{Na}^{+} / \mathrm{K}^{+}$or $\mathrm{Ca}^{2+} / \mathrm{Mg}^{2+}$, both $\mathrm{Na}^{+} / \mathrm{K}^{+}$and $\mathrm{Ca}^{2+} / \mathrm{Mg}^{2+}$, or neither $\mathrm{Na}^{+} / \mathrm{K}^{+}$nor $\mathrm{Ca}^{2+} / \mathrm{Mg}^{2+}$ in single particles, "aggregate" particles, "aggregate with film" particles, "mucus-like" particles, and halo particles. The ions written in brackets in the last column indicate the prevalent type of ion in the respective type of particle.

\begin{tabular}{lrrrr}
\hline & $\begin{array}{r}\mathrm{No} \mathrm{Na}^{+} / \mathrm{K}^{+}, \\
\mathrm{no} \mathrm{Ca}{ }^{2+} / \mathrm{Mg}^{2+}\end{array}$ & $\mathrm{Ca}^{2+} / \mathrm{Mg}^{2+}$ & $\mathrm{Na}^{+} / \mathrm{K}^{+}$ & $\begin{array}{r}\mathrm{Ca}^{2+} / \mathrm{Mg}^{2+} \text { and } \\
\mathrm{Na}^{+} / \mathrm{K}^{+}\end{array}$ \\
\hline Single particles & $4 \%$ & $4 \%$ & $13 \%$ & $78 \%\left(\mathrm{Na}^{+} / \mathrm{K}^{+}\right)$ \\
Aggregate particles & - & - & $20 \%$ & $80 \%\left(\mathrm{Na}^{+} / \mathrm{K}^{+}\right)$ \\
Aggregate with film particles & - & $17 \%$ & $17 \%$ & $67 \%\left(\mathrm{Ca}^{2+} / \mathrm{Mg}^{2+}\right)$ \\
Mucus-like particles & - & $11 \%$ & $3 \%$ & $86 \%\left(\mathrm{Ca}^{2+} / \mathrm{Mg}^{2+}\right)$ \\
Halo particles & $25 \%$ & - & $50 \%$ & $25 \%\left(\mathrm{Na}^{+} / \mathrm{K}^{+}\right)$ \\
\hline
\end{tabular}
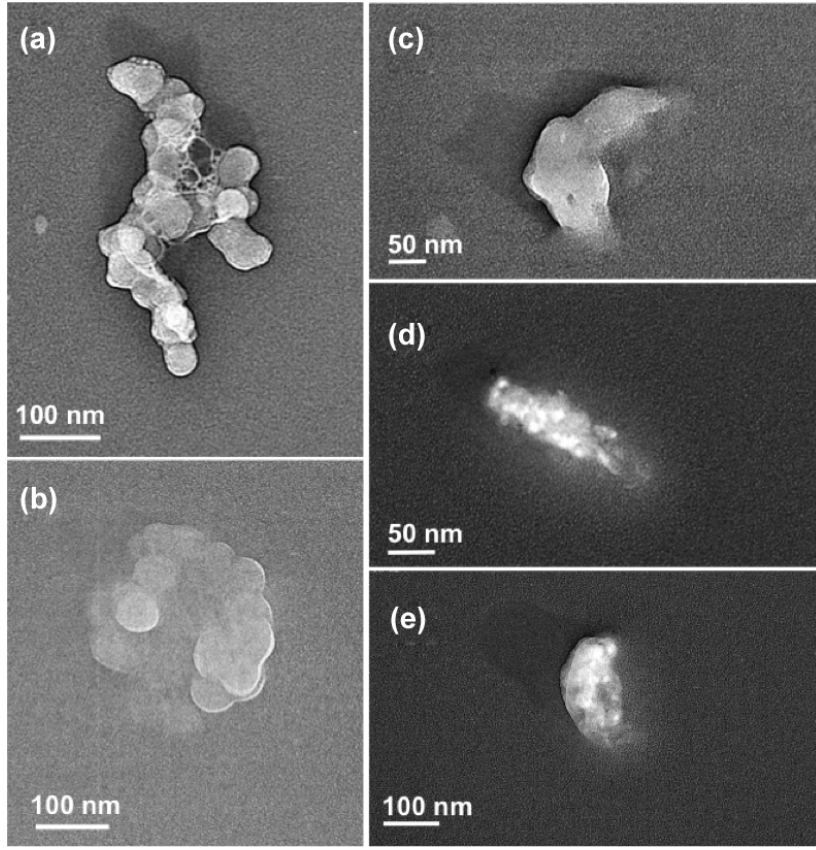

(d)
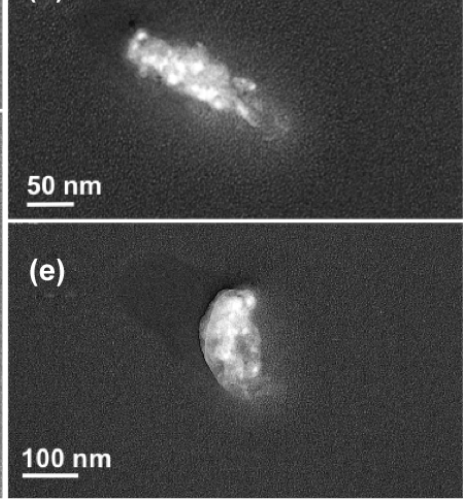

Figure 7. Examples for particles built up by aggregated subunits, observed with TEM: (a, b) pure "aggregate" particles and (c, d, e) "aggregate with film" particles, comprised of "aggregate" particles covered with a thin film of gel.

that were imaged were classified as GP, of which $24 \%$ were observed in the Aitken mode $>45 \mathrm{~nm}$, while $49 \%$ appeared in the accumulation mode between 80 and $200 \mathrm{~nm}$, and $27 \%$ were observed $>200 \mathrm{~nm}$ (Table 1 ).

Particles classified as GP were further evaluated with TEM. The higher resolution of the TEM images revealed better insight into the morphology of the particles and the GP could be further divided into subgroups (Fig. 2). Fourteen percent of the particles (Fig. 5, middle panel) consisted of a conglomeration of smaller spherical subunits that were welded together and formed small chains or agglomerates (Fig. 7a, b). Those particles were named aggregate particles. Twenty-nine percent of the gel particles appeared as aggregate with film particles where aggregate particles were cov- ered with a diffuse and nearly electron-transparent film that partly obscured the underlying subunits and produced a more smooth appearance compared to the bare aggregate particles (Fig. 7c, d and e). However, for the majority of GP, $57 \%$ showed a mucus-like texture that was many times widely outspread on the Formvar film (Fig. 8a, b), partly in long drawn-out structures (Fig. 8c) or with small electron dense inclusions (Fig. 8d).

The individual subunits of aggregate particles and the dense spots in mucus-like particles exhibit diameters between 11 and $109 \mathrm{~nm}$ with a maximum in number size distribution at $39 \mathrm{~nm}$ and a smaller maximum at $28 \mathrm{~nm}$. Figure 9 compares the size distribution of aggregate components from this study (red line) with those from previous studies in the high Arctic and at lower latitudes (Leck and Bigg, 2005a, 2008, 2010). Similarity with previous studies outside and within the pack ice (Leck and Bigg, 2005b; Orellana et al., 2011, same period as this study) strongly suggests the presence of airborne marine gels. Entanglements, ionic or hydrophobic interactions, and/or hydrogen bonds stabilize the three-dimensional biopolymer networks of the marine polymer gels, with electrostatic bonds involving $\mathrm{Ca}^{2+}$ or $\mathrm{Mg}^{2+}$ ions being the most dominating (Verdugo, 2012; Orellana and Leck, 2015). In seawater the observed size of gel particles ranges from solvated nanogels (100-200 nm; Bigg et al., 2004 ) that can further anneal into microgels ( $>1000 \mathrm{~nm}$ ) by interpenetration and entanglement of neighbouring nanogels or hydrophobic interaction. Orellana and Verdugo (2003) have shown that changes in environmental factors like enhanced UV-B radiation will avert gel particle formation or induce fragmentation of existing gel particles in seawater. Changes of $\mathrm{pH}$ and temperature will lead to volume change of the gel polymer assemblies (Tanaka et al., 1980; Orellana et al., 2011). The transport of marine gels from the ocean water into the atmosphere is likely to result in an enhanced exposure of the particles to solar UV-B radiation and might have lead to the fragmentation of airborne gel particles. In cloud processing and the condensation of acidic gases onto the gel particles is suggested to lead to a volume change of the gel particles similar to those observed in seawater and produce gel particles with smaller diameters compared to the 

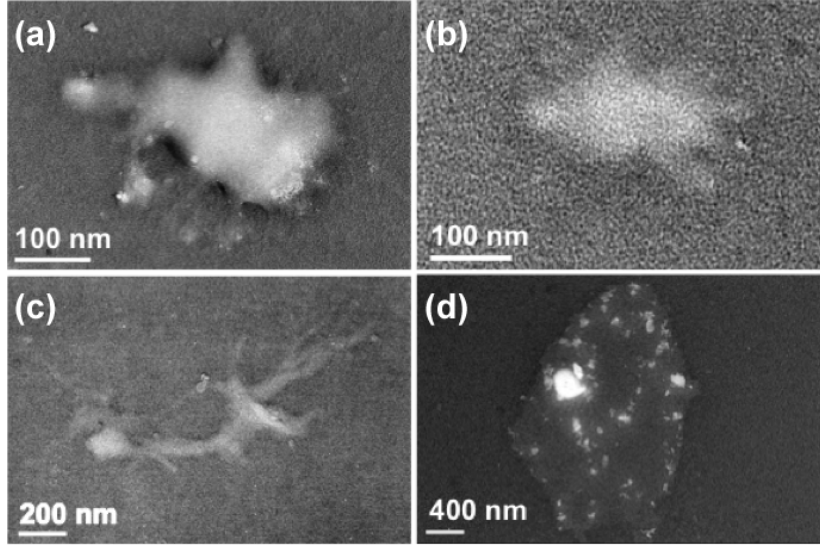

Figure 8. Examples for "mucus-like" particles observed with TEM: (a) mucus matter with small dense inclusions, partly outdrawn on the Formvar film; (b) mucus matter without dense inclusions; (c) mucus matter, extensively outdrawn on the Formvar film; (d) mucus matter with numerous small dense inclusions.

gel particles observed in seawater (Leck and Bigg, 2005b; Orellana et al., 2011).

\subsection{Halo particles}

Besides SP and GP we observed particles with a halo-like appearance (HP) on the TEM grid where a relatively large central particle was surrounded by a droplet ring structure of numerous smaller particles (for examples see Fig. 10).

Several authors (e.g. Farlow et al., 1977; Bigg, 1986; Bigg and Leck, 2001b) have found that the formation of droplet ring structures from sulfuric-acid-containing aerosol is a result of humidity, hydrophilicity of the collection surface, and impact velocity effects. Bigg and Leck (2001b) observed that a solution of sulfuric acid wets out on a hydrophilic surface but retracts when humidity is reduced leaving behind small droplets in a symmetrical ring. In our study, the sampling procedure led to a drastic reduction in RH from around $100 \%$ at ambient conditions to $20 \%$ within the sampling manifold (see Sect. 2.1.1). The aerosol was impacted onto a surface with hydrophilic properties (TEM grid). We will assume that the HP originally existed as one particle in the atmosphere that splashed out into the droplet ring structure upon impaction onto the substrate.

HP comprised $7 \%$ of the total number of aerosol particles (Table 1) and were observed at diameters above $75 \mathrm{~nm}$ and in the accumulation mode with maxima at 161 and $293 \mathrm{~nm}$ (Fig. 5, lower panel). The very weak contrast of the satellite particles against the Formvar background probably has lead to an underestimation of the diameters of HP particles $>100 \mathrm{~nm}$ and shifted number size distribution of the total aerosol to smaller diameters compared to the TDMPS measurements (Fig. 3).

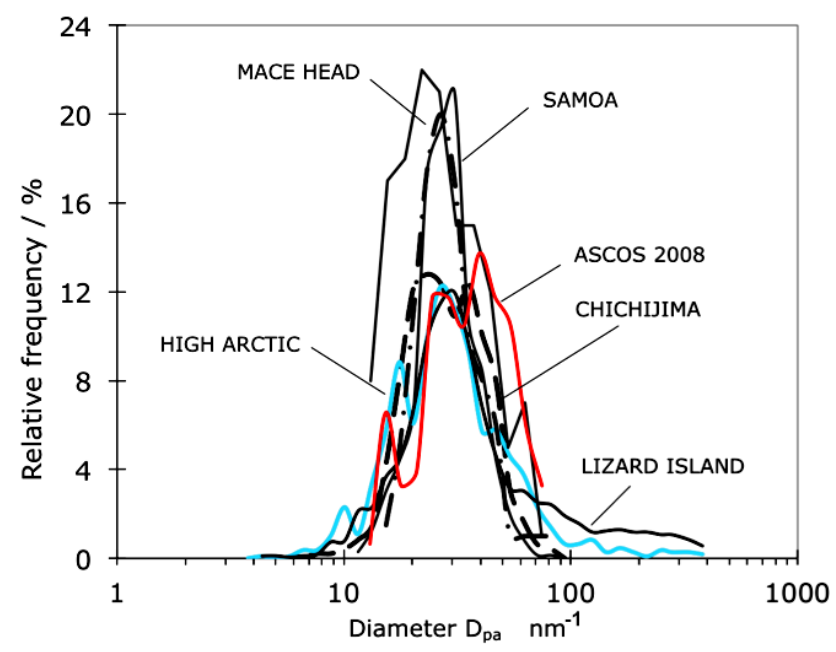

Figure 9. Number size distributions of airborne aggregate particles and their building blocks at different locations: Mace Head $\left(53^{\circ} \mathrm{N}\right.$, $\left.10^{\circ} \mathrm{W}\right)$, Lizard Island $\left(14.6^{\circ} \mathrm{S}, 145.5^{\circ} \mathrm{E}\right)$, American Samoa $\left(14^{\circ} \mathrm{S}\right.$, $172^{\circ} \mathrm{W}$ ), Chichijima $\left(27^{\circ} \mathrm{N}, 142^{\circ} \mathrm{E}\right)$, High Arctic (AOE-2001, between 88.9 and $88.2^{\circ} \mathrm{N}$; light blue line), and ASCOS 2008 (between $87^{\circ} \mathrm{N}, 1^{\circ} \mathrm{W}$ and $87^{\circ} \mathrm{N}, 11^{\circ} \mathrm{W}$; red line). All particles were assumed to be spherical in shape (from Bigg and Leck, 2008, modified).

Imaging with TEM allowed a more detailed investigation of the HP and revealed three morphologically different types of the central particle. We observed central particles in HP that consisted predominantly of skeletal structures of decomposed gel matter or ggregate/aggregate with film particles. Central particles of decomposed gel matter or aggregate/aggregate with film accounted for $19 \%$ and $22 \%$ of the HP. Examples of both particle types are shown in Fig. 10a and b. The majority of central particles (59\%), however, were unstable and seemed to partly evaporate during the imaging process, leaving more transparent structures behind, and were similar to the SP described in Sect. 3.2. We sized the central particles individually in order to compare them with particles of similar morphology within SP or GP. The combined number size distribution of the stable aggregate, aggregate with film, and skeletal central particles exhibited a maximum at $270 \mathrm{~nm}$ in diameter (Fig. $6 \mathrm{~b}$, green line). The number size distribution of unstable central particles showed a maximum at $171 \mathrm{~nm}$ (Fig. 6b lower panel, red line). Unstable SP exhibited a maximum at nearly the same diameter as unstable central particles, at $172 \mathrm{~nm}$ (Fig. 6a upper panel). The consistency in peak position for unstable central particles and unstable SP suggested a similar chemical nature but different atmospheric processing that resulted in condensation of further chemical species and the formation of HP.

The satellites (particulates or droplets) exhibited varying morphologies. Sometimes numerous small satellites surrounded the central particle in a symmetrical ring (Fig. 10a), whereas in other cases the satellite droplets were larger but 

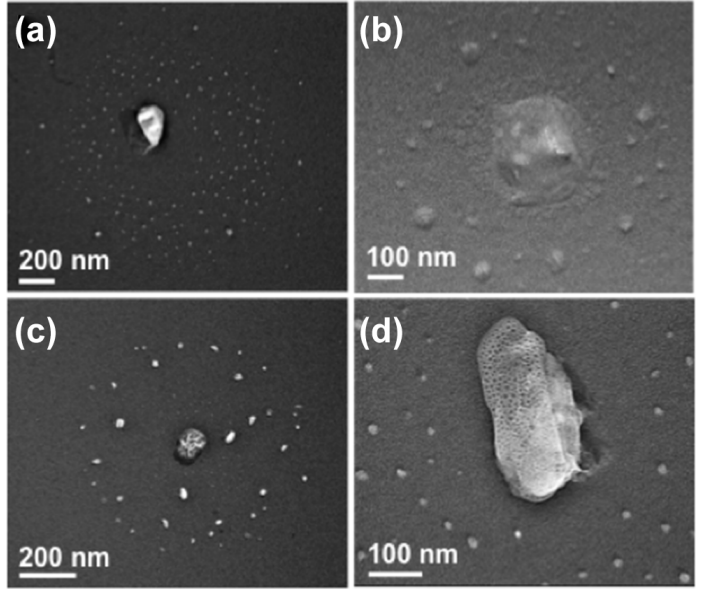

Figure 10. Examples for halo particles observed with TEM. (a) A central "aggregate" particle surrounded by satellite particles of sulfuric acid and a smaller amount of methane sulfonic acid. (b) A central particle of "aggregate with film", surrounded by satellite particles of sulfuric acid and methane sulfonic acid. (c) A central particle of ammonium sulfate, satellite particles formed by methane sulfonic acid, probably mixed with sulfuric acid. (d) A central particle of degenerated gel, surrounded by methane sulfonic acid mixed with sulfuric acid.

fewer (Fig. 10b, c). In the literature three types of compounds have been described to form satellites when airborne aerosol particles impacted on a collection substrate: sulfuric acid (Ayers, 1978; Ferek et al., 1983), ammonium sulfate and bisulfate (Bigg, 1980; Busek and Pósfai, 1999), and methane sulfonic acid (MSA; Bigg et al., 1974). Sulfuric acid exhibits a distinctive morphology: a central particle surrounded by a droplet halo of numerous smaller satellites. Neutralization of sulfuric acid by ammonium or a high content of methane sulfonic acid produces a halo of larger and fewer droplets (Bigg and Leck, 2001a). The morphology of the droplethalos we observed in this study pointed towards the presence of sulfuric acid often in a mixture with ammonium sulfate or bisulfate and/or methane sulfonic acid. As discussed in Sect. 3.2, these sulfur-containing components have been reported not only to be present over the Arctic pack-ice area in summer (Bigg and Leck, 2001a) but also to frequently occur in the remote marine atmosphere (Barnard et al., 1994; Capaldo and Pandis, 1997; Kettle et al., 1999). The observed number size distribution for all HP (Fig. 5, lower panel) is in agreement with results from the high Arctic reported by Hillamo et al. (2001), who observed the first maximum in sulfate-containing aerosol particles at diameters $>80 \mathrm{~nm}$ and in ammonium and MSA-containing particles at diameters $>100 \mathrm{~nm}$.

\subsection{EDX measurements}

To determine the elemental composition of the aerosol samples an EDX spectrometer coupled to TEM was used. EDX spectra of 103 aerosol particles were recorded in conjunction with the imaging process. Molecular dynamics studies on polysaccharides by Li et al. (2013) and Sun et al. (2014) have shown that not only the divalent ions $\mathrm{Ca}^{2+}$ and $\mathrm{Mg}^{2+}$ but also the monovalent ions $\mathrm{Na}^{+}$and $\mathrm{K}^{+}$can stabilize the threedimensional biopolymer gel networks. Inspired by these results, we focused on the detection of those ions in gel-type particles. In the following, we will refer to $\mathrm{Na}^{+}$and $\mathrm{K}^{+}$as $\mathrm{Na}^{+} / \mathrm{K}^{+}$and $\mathrm{Ca}^{2+}$ and $\mathrm{Mg}^{2+}$ as $\mathrm{Ca}^{2+} / \mathrm{Mg}^{2+}$.

The analysis revealed the following characteristics: $\mathrm{Na}^{+} / \mathrm{K}^{+}$was detected in $91 \%$ of the SP. Thirteen percent of these particles contained exclusively $\mathrm{Na}^{+} / \mathrm{K}^{+}$ whereas $78 \%$ contained both types of metal ions, $\mathrm{Na}^{+} / \mathrm{K}^{+}$ and $\mathrm{Ca}^{2+} / \mathrm{Mg}^{2+}$, with the latter only in minor quantities (Fig. 11a; Table 2). Examples of EDX spectra for the different types of particles are shown in Fig. S1 in the Supplement. The aggregate particles contained exclusively $\mathrm{Na}^{+} / \mathrm{K}^{+}$ in $20 \%$ of the particles and predominantly $\mathrm{Na}^{+} / \mathrm{K}^{+}$and minor contents of $\mathrm{Ca}^{2+} / \mathrm{Mg}^{2+}$ in $80 \%$ of the particles (Fig. 11b; Table 2). For the particle types aggregate with film and mucus-like particles, however, a clear dominance of only $\mathrm{Ca}^{2+} / \mathrm{Mg}^{2+}$ was detected. Eighty-four percent of aggregate with film particles contained $\mathrm{Ca}^{2+} / \mathrm{Mg}^{2+}$ as the dominating type of ions. Seventeen percent of the aggregate with film particles contained exclusively $\mathrm{Ca}^{2+} / \mathrm{Mg}^{2+}$ and $67 \%$ of the aggregate with film particles contained $\mathrm{Ca}^{2+} / \mathrm{Mg}^{2+}$ that were accompanied by minor contents of $\mathrm{Na}^{+} / \mathrm{K}^{+}$(Fig. 11c; Table 2). Mucus-like particles also showed a clear dominance of $\mathrm{Ca}^{2+} / \mathrm{Mg}^{2+}$. Eleven percent of mucus-like particles contained exclusively $\mathrm{Ca}^{2+} / \mathrm{Mg}^{2+}$ and $86 \%$ contained $\mathrm{Ca}^{2+} / \mathrm{Mg}^{2+}$ that was accompanied by minor contents of $\mathrm{Na}^{+} / \mathrm{K}^{+}$(Fig. 11d; Table 2). In summary, we observed a gradual transition from particles with a dominating content of $\mathrm{Na}^{+} / \mathrm{K}^{+}$to particles with a dominating content of $\mathrm{Ca}^{2+} / \mathrm{Mg}^{2+}$ moving from SP over aggregate particles and aggregate with film particles to mucus-like particles. Therefore, we hypothesize a connection between the morphology of the particles and the respective dominating cross-linking ion within the polymer three-dimensional network of the marine gels. Li et al. (2013) compared polysaccharides with 3 and 4 repetition units of molecular weights of 1.9 and $2.5 \mathrm{kDa}$ respectively as representations for organic matter in seawater (Verdugo et al., 2004). Their results showed that the assembly of the longer polysaccharide chains seems to be accelerated in the presence of $\mathrm{Ca}^{2+}$, whereas the presence of $\mathrm{Na}^{+}$has a positive effect on the assembly of shorter polysaccharide chains. Considering the observed morphology of the aerosol particles that are built up by marine gel matter, a high content of $\mathrm{Ca}^{2+} / \mathrm{Mg}^{2+}$ could facilitate the formation of fluffy and less compact mucus-like gel matter. The presence of $\mathrm{Na}^{+} / \mathrm{K}^{+}$, however, favoured a more compact structure of type aggregate and SP.

Halo particles with a centre of gel or fraction of a gel showed a high content of $\mathrm{Na}^{+} / \mathrm{K}^{+}: 50 \%$ of the particles contained those metals exclusively whereas another $25 \%$ con- 

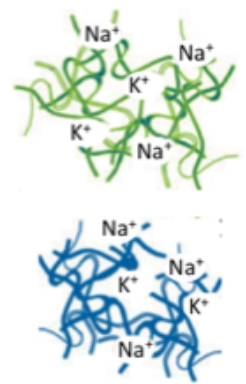

(a)

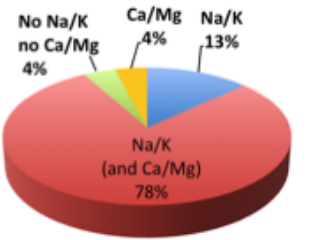

Single particles

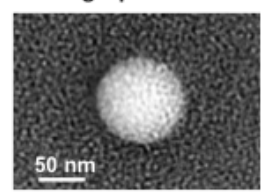

(b)

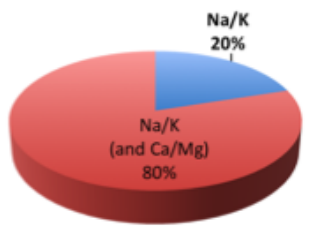

Aggregate particles

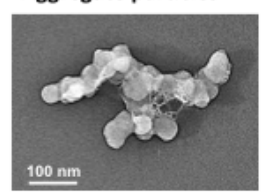

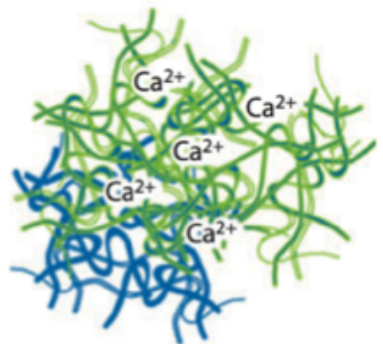

(c)

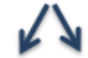

(d)

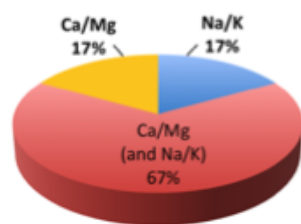

Aggregate with film particle

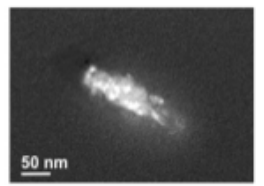

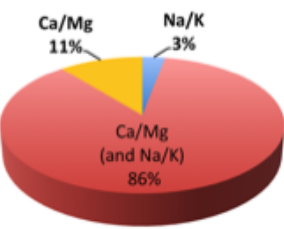

Mucus-like particle

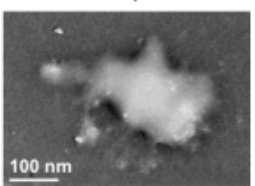

Figure 11. Fraction of particles containing the following ions: $\mathrm{Na}^{+} / \mathrm{K}^{+}$(blue), $\mathrm{Ca}^{2+} / \mathrm{Mg}^{2+}$ (yellow), $\mathrm{Na}^{+} / \mathrm{K}^{+}$and minor contents of $\mathrm{Ca}^{2+} / \mathrm{Mg}^{2+}$ (red), and neither $\mathrm{Na}^{+} / \mathrm{K}^{+}$nor $\mathrm{Ca}^{2+} / \mathrm{Mg}^{2+}$ (green). (a) Single particles comprised of gel matter; (b) "mucus-like" particles; (c) "aggregate" particles; (d) "aggregate with film" particles.

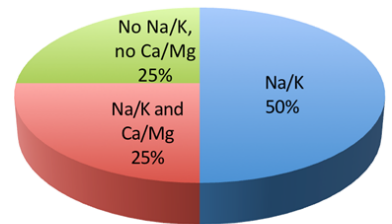

Halo particles

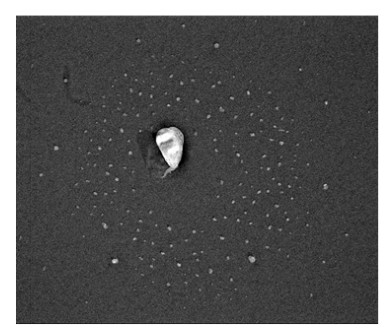

Figure 12. Fraction of $\mathrm{HP}$ containing the following ions: $\mathrm{Na}^{+} / \mathrm{K}^{+}$ (blue), $\mathrm{Na}^{+} / \mathrm{K}^{+}$and $\mathrm{Ca}^{2+} / \mathrm{Mg}^{2+}$ (red), and neither $\mathrm{Na}^{+} / \mathrm{K}^{+}$nor $\mathrm{Ca}^{2+} / \mathrm{Mg}^{2+}$ (green).

tained mainly $\mathrm{Na}^{+} / \mathrm{K}^{+}$with smaller amounts of $\mathrm{Ca}^{2+} / \mathrm{Mg}^{2+}$ (Fig. 12; Table 2). The high content of alkali metal ions in those particles suggested that they originated from SP or fragmented aggregate particles, which were exposed to processes that lead to condensational growth of the original gel particles.

\section{Summary and conclusions}

Aerosol particles collected in the summer high Arctic north of $80^{\circ}$ were individually and objectively investigated with electron microscopy and subsequent image mapping. This enabled a division of the aerosol particles into three sizeresolved gross morphological groups: single particles, gel particles, and halo particles. Single particles dominated the aerosol population in terms of numbers and made up $82 \%$ of all particles; they were observed over the whole submicrometre size range and clearly dominated the Aitken mode. The majority of single particles $(65 \%)$ were stable under the beam of the electron microscope and showed no signs of evaporation or morphological changes during imaging. These particles with refractory properties appeared over the whole size range of particles whereas the remaining $35 \%$ of SP appeared to be heat instable and partly evaporated, and they were predominantly observed in the accumulation mode. Gel particles were observed at diameters $>45 \mathrm{~nm}$ predominantly in the accumulation mode with a maximum at $154 \mathrm{~nm}$ and contributed $11 \%$ to the total particle number. The gel particles exhibited various morphological features and appeared as aggregate particles $(14 \%)$ and as aggregate with film particles (29\%), but the majority (59\%) was made up by mucus-like particles. Seventy percent of the gel particles in our study appeared to be smaller than $100 \mathrm{~nm}$ in diameter, and $90 \%$ were smaller than $200 \mathrm{~nm}$. 
HP appeared mainly in the accumulation mode at diameters $>60 \mathrm{~nm}$ with a maximum at $161 \mathrm{~nm}$ and contributed up to $7 \%$ to the total particle number mapped. The majority of HP consisted of heat instable particles, probably ammonium bisulfate (59\% of all particles), and was internally mixed with sulfur-containing compounds (sulfuric acid, ammonium bisulfate, methane sulfonic acid). The remaining fraction was made up by aggregate particles (19\%) and decomposed or fragmented gel matter $(22 \%)$ internally mixed with sulfurcontaining compounds.

Electron dispersive X-ray (EDX) spectroscopy revealed a gradual transition in the content of $\mathrm{Na}^{+} / \mathrm{K}$ and $\mathrm{Ca}^{2+} / \mathrm{Mg}^{2+}$ between different particle morphologies. SP and aggregate particles preferentially contained $\mathrm{Na}^{+} / \mathrm{K}^{+}$, whereas aggregate with film particles and mucus-like particles contained mainly $\mathrm{Ca}^{2+} / \mathrm{Mg}^{2+}$ with minor contents of $\mathrm{Na}^{+} / \mathrm{K}^{+}$. Supported by model studies (e.g. Li et al., 2013; Sun et al., 2014), we hypothesize a correlation between particle morphology and the presence of the ions $\mathrm{Na}^{+} / \mathrm{K}^{+}$and/or $\mathrm{Ca}^{2+} / \mathrm{Mg}^{2+}$. The prevalence of $\mathrm{Ca}^{2+} / \mathrm{Mg}^{2+}$ facilitates the formation of large organic assemblies of the type gel particle whereas a lack of $\mathrm{Ca}^{2+} / \mathrm{Mg}^{2+}$ and a prevalence of $\mathrm{Na}^{+} / \mathrm{K}^{+}$prohibit the formation of large assemblies and result in smaller entities of the type single particle.

Insufficient knowledge of the size-resolved aerosol composition and especially the role of organic compounds, including their morphology and state of mixture, had hampered a detailed understanding of the processes that lead to the activation of the high Arctic aerosol particles and their role in the formation of cloud droplets so far (Leck and Svensson, 2015; Martin et al., 2011; Zhou et al., 2001; Leck et al., 2002). One evident outcome from this study is that the aerosol particles that would be activated into cloud droplets over the Arctic pack-ice areas cannot be seen as simply inorganic salts. None of the aerosol particles showed an apparent cubic or otherwise crystalline appearance that could be attributed to sea salt particles. The results from this study clearly show that organic marine gel matter significantly contributes to the particle number concentration over the whole sub-micrometre size range, especially at diameters below $60 \mathrm{~nm}$.

A parallel study conducted during the ASCOS campaign (Orellana et al., 2011) demonstrated that airborne aerosol particles contain hydrophobic moieties on their surface that play an important role for gel formation (Maitra et al., 2001) and increase the rate of gel assembly (Ding et al., 2008). The interaction of the hydrophilic and hydrophobic entities on the structure of the polymer gels likely will influence the water vapour pressure and decrease the surface tension of the cloud droplets to be formed (Leck and Svensson, 2015; Ovadnevaite et al., 2011).

Water-soluble particles like ammonium sulfate were present mainly in the accumulation mode at diameters above $100 \mathrm{~nm}$. Growth of the sub-Aitken particles probably resulted from deposition of acids/organic vapours on polymer gel particles and produced HP or sulfur-containing particles with hygroscopic properties typical for a gel nucleus covered by a sulfate-methane sulfonate-ammonium complex. At the same time the fragmentation of larger particles is capable of adding numbers into the Aitken mode (Leck and Bigg, 1999, 2010; Karl et al., 2013). Orellana and Verdugo (2003) and Orellana et al. (2011) observed the sensitivity of marine gels to changes in the physicochemical environment ( $\mathrm{pH}$ and $T$ ) and the fragmentation of gel matter into smaller entities as a result to exposition to UV radiation. Additionally, acidic compounds typically found in the marine atmosphere, like sulfuric acid and DMS, induced volume collapse of the swollen hydrated polymer gel network into a condensed and more compact form (Tanaka et al., 1980; Leck and Bigg, 2010; Orellana et al., 2011). Condensation of sulfur acidic compounds and in-cloud processing of the marine gels in the atmosphere during their passage over the pack ice and continuous exposure to UV radiation due to the length of the polar day in summer could produce smaller sized fragments of marine gels similar to the spherical subunits observed in aggregate/aggregate with film particles and the dense inclusions in mucus-like particles. Since single particles showed a maximum in number concentration in the same size range it cannot be excluded that fragmentation of gel matter or $\mathrm{pH}$ induced collapse of the gel matter lead to the formation of smaller particles and by that provided a mechanism to produce single particles and add particle numbers to the Aitken mode.

In hope of enhancing our understanding on $\mathrm{CCN}$ properties promoting/suppressing cloud droplet formation over the pack-ice area in summer and at the same time meet the demand for observational data for the evaluation of climate models, this study has presented critical size-resolved data on particle morphology, chemical composition, and state of mixture based on the analysis of individual particles.

\section{The Supplement related to this article is available online at doi:10.5194/acp-16-6577-2016-supplement.}

Acknowledgements. This work is part of the ASCOS (Arctic Summer Cloud Ocean Study). ASCOS was an IPY project under the AICIA-IPY umbrella and an endorsed SOLAS project. ASCOS was made possible by funding from the Knut and Alice Wallenberg Foundation, the DAMOCLES Integrated Research Project from the European Union Sixth Framework Program and the Swedish National Research Council (VR). The Swedish Polar Research Secretariat provided access to the icebreaker Oden and logistical support. The authors would like to thank A. Held for collecting the aerosol particles during ASCOS, and A. Öhrström and C. Rauschenberg for their help with sample imaging and EDX measurements.

Edited by: K. Carslaw 


\section{References}

Albrecht, B.: Aerosols, cloud microphysics and fractional cloudiness, Science, 245, 1227-1230, 1989.

Allen, T.: Particle Size Measurement: Volume 1, Chapman \& Hall, London, 1997.

Ayers, G. P.: Quantitative determination of sulfate in individual aerosol particles, Atmos. Environ. 12, 1613-1621, 1978.

Barnard, W. R., Andreae, M. O., and Iverson, R. L.: Dimethylsulfide and Phaeocystis pouchetii in the southeastern Bering Sea, Cont. Shelf Res., 3, 103-113, 1984.

Bates, T. S., Cline, J. D., Gammon, R. H., and Kelly-Hansen, S. R.: Regional and seasonal variations in the flux of oceanic dimethylsulfide to the atmosphere, J. Geophys. Res., 92, 2930-2938, doi:10.1029/JC092iC03p02930, 1987.

Bigg, E. K.: Comparison of Aerosol at Four Baseline Atmospheric Monitoring Stations, J. Appl. Meteorol., 19, 521-533, 1980.

Bigg, E. K.: Ammonium compounds in stratospheric aerosols, Tellus B, 38, 62-66, 1986.

Bigg, E. K. and Leck, C.: Cloud-active particles over the central Arctic Ocean, J. Geophys. Res., 106, 32155-32166, doi:10.1029/1999JD901152, 2001a.

Bigg, E. K. and Leck, C.: Properties of the aerosol over the central Arctic Ocean, J. Geophys. Res., 106, 32101-32109, doi:10.1029/1999JD901136, 2001b.

Bigg, E. K. and Leck, C.: The composition of fragments of bubbles bursting at the ocean surface, J. Geophys. Res. 113, D11209, doi:10.1029/2007JD009078, 2008.

Bigg, E. K., Ono, A., and Williams, J. A.: Chemical tests for individual submicron aerosol particles, Atmos. Environ., 8, 1-13, 1974.

Bigg, E. K., Leck, C., and Nilsson, E. D.: Sudden changes in arctic atmospheric aerosol concentrations during summer and autumn, Tellus B, 48, 254-271, doi:10.1034/j.1600-0889.1996.t011-00009.x, 1996.

Bigg, E. K., Leck, C., and Tranvik, L.: Particulates of the surface microlayer of open water in the central Arctic Ocean in summer, Mar. Chem., 91, 131-141, 2004.

Blanchard, D. C.: The oceanic production of volatile cloud nuclei, J. Atmos. Sci., 28, 811-812, doi:10.1175/15200469(1971)028<0811:TOPOVC>2.0.CO;2, 1971.

Blanchard, D. C. and Syzdeck, L. D.: Filmdrop production as a function of bubble size, J. Geophys. Res., 93, 3649-3654, doi:10.1029/JC093iC04p03649, 1988.

Blanchard, D. C. and Woodcock, A. H.: Bubble formation and modification in the sea and its meteorological significance, Tellus, 9, 145-158, doi:10.1111/j.2153-3490.1957.tb01867.x, 1957.

Busek, P. R. and Pósfai, M.: Airborne minerals and related aerosol particles: effects on climate and the environment, P. Natl. Acad. Sci. USA, 96, 3372-3379, 1999.

Capaldo, K. P. and Pandis, S. N.: Dimethylsulfide chemistry in the remote marine atmosphere: Evaluation and sensitivity analysis of available mechanisms, J. Geophys. Res., 102, 23251-23267, 1997.

Carslaw, K. S., Lee, A., Reddington, C. L., Pringle, K. J., Rap, A., Forster, P. M., Mann, G. W., Spracklen, D. V., Woodhouse, M. T., Regayre, L. A., and Pierce, J. R.: Large contribution of natural aerosols to uncertainty in indirect forcing, Nature, 503, 67-71, doi:10.1038/nature12674, 2013.
Chi, J. W., Li, W. J., Zhang, D. Z., Zhang, J. C., Lin, Y. T., Shen, X. J., Sun, J. Y., Chen, J. M., Zhang, X. Y., Zhang, Y. M., and Wang, W. X.: Sea salt aerosols as a reactive surface for inorganic and organic acidic gases in the Arctic troposphere, Atmos. Chem. Phys., 15, 11341-11353, doi:10.5194/acp-15-11341-2015, 2015.

Chin, W.-C., Orellana, M. V., and Verdugo, P.: Spontaneous assembly of marine dissolved organic matter into polymer gels, Nature, 391, 568-572, 1998.

Covert, D. S., Wiedensohler, A., Aalto, P., Heintzenberg, J., McMurry, P. H., and Leck, C.: Aerosol number size distributions from 3 to $500 \mathrm{~nm}$ diameter in the arctic marine boundary layer during summer and autumn, Tellus B, 48, 197-212, 1996.

Ding, Y.-X., Chin, W.-C., Rodriguez, A., Hung, C.-C., Santschi, P. H., and Verdugo, P.: Amphiphilic exopolymers from Sagittula stellata induce DOM self-assembly and formation of marine microgels, Mar. Chem., 112, 11-19, 2008.

Dixkens, J. and Fissan, H.: Development of an Electrostatic Precipitator for Off-Line Particle Analysis, Aerosol. Sci. Tech., 30, 438-453, 1999.

Douglas, T. and Sturm, M.: Arctic haze, mercury and the chemical composition of snow across northwestern Alaska, Atmos. Environ., 38, 805-820, 2004.

Egerton, R. F.: Physical Principles of Electron Microscopy, Springer, New York, USA, 2008.

Engvall, A.-C., Krejci, R., Ström, J., Treffeisen, R., Scheele, R., Hermansen, O., and Paatero, J.: Changes in aerosol properties during spring-summer period in the Arctic troposphere, Atmos. Chem. Phys., 8, 445-462, doi:10.5194/acp-8-445-2008, 2008.

Farlow, N. H., Hayes, D. M., and Lem, H. Y.: Stratospheric aerosols: undissolved granules and physical state, J. Geophys. Res., 82, 4921-4929, 1977.

Ferek, R. J., Lazrus, A. L., and Winchester, W.: Electron microscopy of acidic aerosols collected over the northeastern United States, Atmos. Environ., 17, 1545-1561, 1983.

Forster, P., Ramaswamy, V., Artaxo, P., Berntsen, T., Betts, R., Fahey, D. W., Haywood, J., Lean, J., Lowe, D. C., Myhre, G., Nganga, J., Prinn, R., Raga, G., Schulz, M., and Van Dorland, R.: Changes in atmospheric constituents and in radiative forcing, in: Climate Change 2007: The Physical Science Basis. Contribution of Working Group I to the Fourth Assessment Report of the Intergovernmental Panel on Climate Change, edited by: Solomon, S., Qin, D., Manning, M., Chen, Z., Marquis, M., Averyt, K. B., Tignor, M., and Miller, H. L., Cambridge University Press, Cambridge, United Kingdom and New York, NY, USA, 2007.

Geng, H., Ryu, J., Jung, H.-J., Chung, H., Ahn, K.-H., and Ro, C.-U.: Single-Particle Characterization of Summertime Arctic Aerosols Collected at Ny-Alesund, Svalbard, Environ. Sci. Technol., 44, 2348-2353, 2010.

Gershey, R. M.: Characterization of seawater organic matter carried by bubble generated aerosols, Limnol. Oceanogr., 28, 309-319, doi:10.4319/lo.1983.28.2.0309, 1983.

Hamacher-Barth, E., Jansson, K., and Leck, C.: A method for sizing submicrometer particles in air collected on Formvar films and imaged by scanning electron microscope, Atmos. Meas. Tech., 6, 3459-3475, doi:10.5194/amt-6-3459-2013, 2013.

Hara, K., Yamagata, S., Yamanouchi, T., K. Sato, K., Herber, A., Iwasaka, Y., Nagatani, M., and Nakata, H.: Mixing states of individual aerosol particles in spring Arctic troposphere during 
ASTAR 2000 campaign, J. Geophys. Res.-Atmos., 108, 4209, doi:10.1029/2002JD002513, 2003.

Heard, M. J. and Wiffen, R. D.: Electron microscopy of natural aerosols and the identification of particulate ammonium sulfate, Atmos. Environ., 3, 337-340, 1969.

Heintzenberg, J. and Leck, C.: Seasonal variations of the atmospheric aerosol near the top of the marine boundary layer over Spitsbergen related to the Arctic sulfur cycle, Tellus B, 46, 5267, 1994.

Heintzenberg, J. and Leck, C.: The summer aerosol in the central Arctic 1991-2008: did it change or not?, Atmos. Chem. Phys., 12, 3969-3983, doi:10.5194/acp-12-3969-2012, 2012.

Heintzenberg, J., Leck, C., Birmili, W., Wehner, B., Tjernström, M., and Wiedensohler, A.: Aerosol number-size distributions during clear and fog periods in the summer high Arctic: 1991, 1996 and 2001, Tellus B, 58, 41-50, doi:10.1111/j.16000889.2005.00171.x, 2006.

Heintzenberg, J., Leck, C., and Tunved, P.: Potential source regions and processes of aerosol in the summer Arctic, Atmos. Chem. Phys., 15, 6487-6502, doi:10.5194/acp-15-6487-2015, 2015.

Held, A., Brooks, I. M., Leck, C., and Tjernström, M.: On the potential contribution of open lead particle emissions to the central Arctic aerosol concentration, Atmos. Chem. Phys., 11, 3093 3105, doi:10.5194/acp-11-3093-2011, 2011a.

Held, A., Orsini, D. A., Vaattovaara, P., Tjernström, M., and Leck, C.: Near-surface profiles of aerosol number concentration and temperature over the Arctic Ocean, Atmos. Meas. Tech., 4, 1603-1616, doi:10.5194/amt-4-1603-2011, 2011 b.

Hillamo, R., Kerminen, V.-M., Aurela, M., Mäkelä, T., Maenhaut, W., and Leck, C.: Modal structure of chemical mass size distribution in the high Arctic aerosol, J. Geophys. Res., 106, 2755527571, doi:10.1029/2001JD001119, 2001.

Hinds, W.: Aerosol Technology, 2nd Edn., John Wiley \& Sons, New York, 1999.

Hoppel, W. A., Frick, G. M., and Larson, R. E.: Effect of nonprecipitating clouds on the aerosol size distribution in the marine boundary layer, Geophys. Res. Lett., 13, 125-128, 1986.

Johnson, B. D. and Wangersky, P. J.: Microbubbles - stabilization by monolayers of adsorbed particles, J. Geophys. Res.-Oceans, 92, 14641-14647, doi:10.1029/JC092iC13p14641, 1987.

Karl, M., Leck, C., Coz, E., and Heintzenberg, J.: Marine nanogels as a source of atmospheric nanoparticles in the high Arctic, Geophys. Res. Lett., 40, 3738-3743, 2013.

Kettle, A. J., Andreae, M. O., Amouroux, D., Andreae, T. W., Bates, T. S., Berresheim, H., Bingemer, H., Boniforti, R., Curran, M. A. J., DiTullio, G. R., Helas, G., Jones, G. B., Keller, M. D., Kiene, R. P., Leck, C., Levasseur, M., Maspero, M., Matrai, P., McTaggat, A. R., Mihalopoulos, N., Nguyen, B. C., Novo, A., Putaud, J. P., Rapsomanikis, S., Roberts, G., Schebeske, G., Sharma, S., Simo, R., Staubes, R., Turner, S., and Uher, G.: A global database of sea surface dimethylsulphide (DMS) measurements and a simple model to predict sea surface DMS as a function of latitude, longitude and month, Global Biogeochem. Cy., 13, 399-444, 1999.

Korhonen, H., Carslaw, K. S., Spracklen, D. V., Ridley, D. A., and Ström, J.: A global model study of processes controlling aerosol size distributions in the Arctic spring and summer, J. Geophys. Res., 113, D08211, doi:10.1029/2007JD009114, 2008.
Kuhn, T., Damoah, R., Bacak, A., and Sloan, J. J.: Characterising aerosol transport into the Canadian High Arctic using aerosol mass spectrometry and Lagrangian modelling, Atmos. Chem. Phys., 10, 10489-10502, doi:10.5194/acp-10-10489-2010, 2010.

Lannefors, H., Heintzenberg, J., and Hansson, H.-C.: A comprehensive study of physical and chemical parameters of the Arctic summer aerosol; results from the Swedish expedition Ymer-80, Tellus B, 35, 40-54, 1983.

Leck, C. an Bigg, E. K.: Aerosol production over remote marine areas - a new route, Geophys. Res. Lett., 26, 3577-3580, 1999.

Leck, C. and Bigg, E. K.: Evolution of marine aerosol - a new perspective, Geophys. Res. Lett., 32, L19803, doi:10.1029/2005GL023651, 2005a.

Leck, C. and Bigg, E. K.: Biogenic particles in the surface microlayer and overlaying atmosphere in the central Arctic Ocean during summer, Tellus B, 57, 305-316, doi:10.1111/j.16000889.2005.00148.x, 2005b.

Leck, C. and Bigg, E. K.: Comparison of sources and nature of the tropical aerosol with the summer high Arctic aerosol, Tellus B, 60, 118-126, 2008.

Leck, C. and Bigg, E. K.: New particle formation of marine biological origin, Aerosol Sci. Tech., 44, 570-577, 2010.

Leck, C. and Nilsson, D. E.: A pseudo-Lagrangian study of the sulfur budget in the remote Arctic marine boundary layer, Tellus B, 54, 213-230, 2002.

Leck, C. and Svensson, E.: Importance of aerosol composition and mixing state for cloud droplet activation over the Arctic pack ice in summer, Atmos. Chem. Phys., 15, 2545-2568, doi:10.5194/acp-15-2545-2015, 2015.

Leck, C., Bigg, E. K., Covert, D. S., Heintzenberg, J., Maenhaut, W., Nilsson, E. D., and Wiedensohler, A.: Overview of the atmospheric research program during the International Arctic Ocean Expedition 1991 (IAOE-91) and its scientific results, Tellus B, 48, 136-155, 1996.

Leck, C., Nilsson, E. D., Bigg, E. K., and Bäcklin, L.: The atmospheric program of the Arctic Ocean Expedition 1996 (AOE-96): An overview of scientific goals, experimental approach, and instruments, J. Geophys. Res., 106, 32051-32067, 2001.

Leck, C., Norman, M., Bigg, E. K., and Hillamo, R.: Chemical composition and sources of the high Arctic aerosol relevant for cloud formation, J. Geophys. Res., 107, 4135-4153, doi:10.1029/2001JD001463, 2002.

Leck, C., Tjernström, M., Matrai, P., Swietlicki, E., and Bigg, E. K.: Can marine micro-organisms influence melting of the Arctic pack ice?, EOS, 85, 25-36, 2004.

Leck, C., Gao, Q., Mashayekhy Rad, F., and Nilsson, U.: Size-resolved atmospheric particulate polysaccharides in the high summer Arctic, Atmos. Chem. Phys., 13, 12573-12588, doi:10.5194/acp-13-12573-2013, 2013.

Lee, L. A., Pringle, K. J., Reddington, C. L., Mann, G. W., Stier, P., Spracklen, D. V., Pierce, J. R., and Carslaw, K. S.: The magnitude and causes of uncertainty in global model simulations of cloud condensation nuclei, Atmos. Chem. Phys., 13, 8879-8914, doi:10.5194/acp-13-8879-2013, 2013.

Li, X., Leck, C., Sun, L., Hede, T., Tu, Y., and Ågren, H.: Cross-linked polysaccharide assemblies in marine gels: an atomistic simulation, J. Phys. Chem. Lett., 4, 2637-2642, doi:10.1021/jz401276r, 2013. 
Lohmann, U. and Leck, C.: Importance of submicron surface-active organic aerosols for pristine Arctic clouds, Tellus B, 57, 261268, 2005.

Maitra, U., Mukhpadhyay, S., Sarkar, A., Rao, P., and Indi, S. S.: Hydrophobic pockets in a nonpolymeric aqueous gel: observation of such a gelation process by color change, Angew. Chem. Int., 40, 2281-2283, 2001.

Mancuso-Nichols, C. A., Guezennec, J., and Bowman, J. P.: Bacterial exopolysaccharides from extreme marine environments, with special consideration of the Southern Ocean, sea ice and hydrothermal vents: a review, J. Appl. Microbiol., 96, 1057-1066, 2005.

Mann, G. W., Carslaw, K. S., Reddington, C. L., Pringle, K. J., Schulz, M., Asmi, A., Spracklen, D. V., Ridley, D. A., Woodhouse, M. T., Lee, L. A., Zhang, K., Ghan, S. J., Easter, R. C., Liu, X., Stier, P., Lee, Y. H., Adams, P. J., Tost, H., Lelieveld, J., Bauer, S. E., Tsigaridis, K., van Noije, T. P. C., Strunk, A., Vignati, E., Bellouin, N., Dalvi, M., Johnson, C. E., Bergman, T., Kokkola, H., von Salzen, K., Yu, F., Luo, G., Petzold, A., Heintzenberg, J., Clarke, A., Ogren, J. A., Gras, J., Baltensperger, U., Kaminski, U., Jennings, S. G., O’Dowd, C. D., Harrison, R. M., Beddows, D. C. S., Kulmala, M., Viisanen, Y., Ulevicius, V., Mihalopoulos, N., Zdimal, V., Fiebig, M., Hansson, H.-C., Swietlicki, E., and Henzing, J. S.: Intercomparison and evaluation of global aerosol microphysical properties among AeroCom models of a range of complexity, Atmos. Chem. Phys., 14, 4679-4713, doi:10.5194/acp-14-4679-2014, 2014.

Martin, M., Chang, R. Y.-W., Sierau, B., Sjogren, S., Swietlicki, E., Abbatt, J. P. D., Leck, C., and Lohmann, U.: Cloud condensation nuclei closure study on summer arctic aerosol, Atmos. Chem. Phys., 11, 11335-11350, doi:10.5194/acp-11-11335-2011, 2011.

Mauritsen, T., Sedlar, J., Tjernström, M., Leck, C., Martin, M., Shupe, M., Sjogren, S., Sierau, B., Persson, P. O. G., Brooks, I. M., and Swietlicki, E.: An Arctic CCN-limited cloud-aerosol regime, Atmos. Chem. Phys., 11, 165-173, doi:10.5194/acp-11165-2011, 2011.

Medwin, H.: In-situ acoustic measurements of bubble populations in coastal ocean waters, J. Geophys. Res., 75, 599-611, doi:10.1029/JC075i003p00599, 1970.

Mészáros, A. and Vissy, K.: Concentration, size distribution and chemical nature of atmospheric aerosol particles in remote oceanic areas, J. Aerosol Sci., 5, 101-110, 1974.

Michael, J. R., Joy, D. C., and Griffin, B. J.: Use of sample bias voltage for low-energy high-resolution imaging in the SEM, Microsc. Microanal., 16, 614-615, doi:10.1017/S1431927610055315, 2010.

Nilsson, D. E. and Leck, C.: A pseudo-Lagrangian study of the sulfur budget in the remote Arctic marine boundary layer, Tellus B, 54, 213-230, 2002.

Norris, S. J., Brooks, I. M., de Leeuw, G., Sirevaag, A., Leck, C., Brooks, B. J., Birch, C. E., and Tjernström, M.: Measurements of bubble size spectra within leads in the Arctic summer pack ice, Ocean Sci., 7, 129-139, doi:10.5194/os-7-129-2011, 2011.

O'Dowd, C. D., Lowe, J. A., Smith, M. H., and Kaye, M. H.: The relative importance of non-sea-salt sulphate and sea-salt aerosol to the marine cloud condensation nuclei population: An improved multi-component aerosol-cloud droplet parametrization, Q. J. Roy. Meteor. Soc., 125, 1295-1313, 1999.
Okada, K.: Nature of individual hygroscopic particles in the urban atmosphere, J. Meteorol. Soc. Jpn., 61, 727-735, 1983.

Orellana, M. V. and Leck, C.: Marine microgels in: Biogeochemistry of Marine Dissolved Organic Matter, 2nd Edn., 451-480, doi:10.1016/B978-0-12-405940-5.00009-1, 2015.

Orellana, M. V. and Verdugo, P.: Ultraviolet radiation blocks the organic carbon exchange between the dissolved phase and the gel phase in the ocean, Limnol. Oceanogr., 48, 1618-1623, 2003.

Orellana, M. V., Matrai, P. A., Leck, C., Rauschenberg, C. D., Lee, A. M., and Coz, E.: Marine microgels as a source of cloud condensation nuclei in the high Arctic, P. Natl. Acad. Sci., 108, 13612-13617, doi:10.1073/pnas.1102457108, 2011.

Ovadnevaite, J., Ceburnis, D., Martucci, G., Bialek, J., Monahan, C., Rinaldi, M., Facchini, M. C., Berresheim, H., Worsnop, D. R., and O'Dowd, C.: Primary marine organic aerosol: A dichotomy of low hygroscopicity and high CCN activity, Geophys. Res. Lett., 38, L21806, doi:10.1029/2011GL048869, 2011.

Penner, J. E., Andreae, M., Annegarn, H., Barrie, L., Feichter, J., Hegg, D., Jayaraman, A., Leaitch, R., Murphy, D., Nganga, J., and Pitar, G.: Aerosols, their Direct and Indirect Effects, in: Climate Change 2001: The Scientific Basis, Contribution of Working Group I to the Third Assessment Report of the Intergovernmental Panel on Climate Change, edited by: Houghton, J. T., Ding, Y., Griggs, D. J., Noguer, M., van der Linden, P. J., Dai, X., Maskell, K., and Johnson, C. A., Cambridge University Press, Cambridge, United Kingdom and New York, NY, USA, 2001.

Quinn, P. K., Charlson, R. J., and Zoller, W. H.: Ammonia, the dominant base in the remote marine troposphere: a review, Tellus B, 39, 413-425, 1987.

Rao, K. V. R., Hariharan, P. L., Jagannathan, K., and Yoganarasimhan, S. R.: Scanning electron microscopy of ammonium nitrate prills in relation to their application in ammonium nitrate-fuel oil systems, Fuel, 68, 1118-1122, doi:10.1016/00162361(89)90181-6, 1989.

Rocha, S., Krastev, R., Thünemann, A. F., Pereira, M. C., Möhwald, H., and Bezesinski, G.: Adsorption of amyloid ß-peptide at polymer surfaces: a neutron reflectivity study, Chem. Phys. Chem., 6, 2527-2534, doi:10.1002/cphc.200500158, 2005.

Schimel, D., Alves, D., Enting, I., Heimann, M., Joos, F., Raynaud, D., Wigley, T., Prather, M., Derwent, R., Ehhalt, D., Fraser, P., Sanhueza, E., Zhou, X., Jonas, P., Charlson, R., Rodhe, H., Sadasivan, S., Shine, K. P., Fouquart, Y., Ramaswamy, V., Solomon, S., Srinivasan, J., Albritton, D., Isaksen, I., Lal, M., and Wuebbles, D.: Radiative forcing of climate change, in: Climate Change 1996, Contribution of Working Group I to the 2nd Assessment Report of the Intergovernmental Panel on Climate Change, edited by: Houghton, J. T., Meira Filho, L. G., Callander, B. A., Harris, N., Kattenberg, A., and Maskell, K., Cambridge University Press, Cambridge, United Kingdom and New York, NY, USA, 1996.

Shaw, G. E.: Microparticle size spectrum of Arctic haze, Geophys. Res. Lett., 11, 409-412, 1984.

Shaw, G. E.: The arctic haze phenomenon, B. Am. Meteorol. Soc., 76, 2403-2413, 1995.

Solomon, S., Quin, D., Manning, M., Chen, Z., Marquis, M., Averyt, K. B., Tignor, M., and Miller, H. L.: Climate change 2007: The physical science basis, Cambridge University Press, 996 pp., 2007.

Söderlund, R.: Ammonia in the atmosphere, PhD dissertation, University of Stockholm, Stockholm, Sweden, 1982. 
Stevens, S. M., Jansson, K., Xiao, C., Asahina, S., Klingstedt, M., Grüner, D., Sakamoto, Y., Keiichi, M., Cubillas, P., Brent, R., Han, L., Che, S., Ryoo, R., Zhao, D., Anderson, M., Schüth, F., and Terasaki, O.: An Appraisal of High Resolution Scanning Electron Microscopy to Porous Material, JEOL news, 44, 17-22, 2009.

Stohl, A.: Characteristics of atmospheric transport into the Arctic troposphere, J. Geophys. Res., 111, D11306, doi:10.1029/2005JD006888, 2006.

Stolzenburg, M. R.: An ultrafine aerosol size distribution measuring system, PhD Thesis, University of Minnesota, Minneapolis, USA, 1988.

Ström, J., Umegård, K., Tørseth, K., Tunved, P., Hansson, H.-C., Holmén, K., Wismann, V., Herver, A., and König-Langlo, G.: One year of particle size distribution and aerosol chemical composition measurements at the Zeppelin station, Svalbard, March 2000-2001, Phys. Chem. Earth, 28, 1181-1190, 2003.

Sun, L., Li, X., Hede, T., Tu, Y., Leck, C., and Ågren, H.: Molecular dynamics simulations reveal the assembly mechanisms of polysaccharides in marine aerosols, Phys. Chem. Chem. Phys., 16, 25935-25941, 2014.

Tanaka, T., Fillmore, D., Sun, S., Nishio, I., Wislow, G. S., and Shah, A.: Phase transitions in ionic gels, Phys. Rev. Lett., 45, 1636-1642, 1980.

Tjernström, M., Birch, C. E., Brooks, I. M., Shupe, M. D., Persson, P. O. G., Sedlar, J., Mauritsen, T., Leck, C., Paatero, J., Szczodrak, M., and Wheeler, C. R.: Meteorological conditions in the central Arctic summer during the Arctic Summer Cloud Ocean Study (ASCOS), Atmos. Chem. Phys., 12, 6863-6889, doi:10.5194/acp-12-6863-2012, 2012.

Tjernström, M., Leck, C., Birch, C. E., Bottenheim, J. W., Brooks, B. J., Brooks, I. M., Bäcklin, L., Chang, R. Y.-W., de Leeuw, G., Di Liberto, L., de la Rosa, S., Granath, E., Graus, M., Hansel, A., Heintzenberg, J., Held, A., Hind, A., Johnston, P., Knulst, J., Martin, M., Matrai, P. A., Mauritsen, T., Müller, M., Norris, S. J., Orellana, M. V., Orsini, D. A., Paatero, J., Persson, P. O. G., Gao, Q., Rauschenberg, C., Ristovski, Z., Sedlar, J., Shupe, M. D., Sierau, B., Sirevaag, A., Sjogren, S., Stetzer, O., Swietlicki, E., Szczodrak, M., Vaattovaara, P., Wahlberg, N., Westberg, M., and Wheeler, C. R.: The Arctic Summer Cloud Ocean Study (ASCOS): overview and experimental design, Atmos. Chem. Phys., 14, 282-2869, doi:10.5194/acp-14-2823-2014, 2014.

Twomey, S. A.: The influence of pollution on the shortwave albedo of clouds, J. Atmos. Sci., 34, 1149-1152, 1977.

Verdugo, P.: Marine microgels, Annu. Rev. Mar. Sci., 4, 375-400, 2012.
Verdugo, P., Alldredge, A. L., Azam, F., Kirchman, D. L., Passow, U., and Santschi, P. H.: The oceanic gel phase: a bridge in the DOM-POM continuum, Mar. Chem., 92, 67-85, 2004.

Wettlaufer, J. S.: Introduction to Crystallization Phenomena in Natural and Artificial Sea Ice, in: Physics of Ice-Covered Seas, edited by: Lepparanta, M., University of Helsinki Press, Helsinki, 105-194, 1998.

Wiedensohler, A., Birmili, W., Nowak, A., Sonntag, A., Weinhold, K., Merkel, M., Wehner, B., Tuch, T., Pfeifer, S., Fiebig, M., Fjäraa, A. M., Asmi, E., Sellegri, K., Depuy, R., Venzac, H., Villani, P., Laj, P., Aalto, P., Ogren, J. A., Swietlicki, E., Williams, P., Roldin, P., Quincey, P., Hüglin, C., Fierz-Schmidhauser, R., Gysel, M., Weingartner, E., Riccobono, F., Santos, S., Grüning, C., Faloon, K., Beddows, D., Harrison, R., Monahan, C., Jennings, S. G., O’Dowd, C. D., Marinoni, A., Horn, H.-G., Keck, L., Jiang, J., Scheckman, J., McMurry, P. H., Deng, Z., Zhao, C. S., Moerman, M., Henzing, B., de Leeuw, G., Löschau, G., and Bastian, S.: Mobility particle size spectrometers: harmonization of technical standards and data structure to facilitate high quality long-term observations of atmospheric particle number size distributions, Atmos. Meas. Tech., 5, 657-685, doi:10.5194/amt5-657-2012, 2012.

Williams, D. B. and Carter, C. B.: Transmission Electron Microscopy, A textbook for materials science, Part I: Transmission electron microscopy, Springer Science + Buisiness Media, New York, USA, 354 pp., 1996.

Winiger, P., Andersson, A., Yttri, K. E., Tunved, P., and Gustafsson, Ö.: Isotope-based source appointment of EC aerosol particles during winter high-pollution events at the Zeppelin Observatory, Svalbard, Environ. Sci. Techol., 49, 11959-11966, doi:10.1021/acs.est.5b02644, 2015.

Wotton, R. S. and Preston, T. M.: Surface films - areas of water bodies that are often overlooked, BioScience, 55, 137-145, 2005.

Xie, Z., Blum, J. D., Utsunomiya, S., Ewing, R. C., Wang, X., and Sun, L.: Summertime carbonaceous aerosols collected in the marine boundary layer of the Arctic Ocean, J. Geophys. Res., 112, D02306, doi:10.1002/cphc.200500158, 2007.

Zhou, J., Swietlicki, E., Berg, O. H., Aalto, P. P., Hämeri, K., Nilsson, E. D., and Leck, C.: Hygroscopic properties of aerosol particles over the central Arctic Ocean during summer, J. Geophys. Res., 106, 32111-32123, 2001.

Zhou, W., Apkarian, R., Wang, Z. L., and Joy, D.: Fundamentals of scanning electron microscopy, in: Scanning Microscopy for Nanotechnology - Techniques and Applications, edited by: Zhou, W. and Wang, Z. L., Springer Business + Media, New York, 2006. 